\title{
Methodiek en structuur arbeidsmarktmodule I-see! 1991
}

Citation for published version (APA):

Dekker, R., de Grip, A., Berendsen, H., Wieling, M., \& Willems, E. J. T. A. (1992). Methodiek en structuur arbeidsmarktmodule l-see! 1991. Researchcentrum voor Onderwijs en Arbeidsmarkt, Faculteit der Economische Wetenschappen. ROA Working Papers No. 1 https://doi.org/10.26481/umarow.1992001

Document status and date:

Published: 01/01/1992

DOI:

10.26481/umarow.1992001

Document Version:

Publisher's PDF, also known as Version of record

\section{Please check the document version of this publication:}

- A submitted manuscript is the version of the article upon submission and before peer-review. There can be important differences between the submitted version and the official published version of record.

People interested in the research are advised to contact the author for the final version of the publication, or visit the DOI to the publisher's website.

- The final author version and the galley proof are versions of the publication after peer review.

- The final published version features the final layout of the paper including the volume, issue and page numbers.

Link to publication

\footnotetext{
General rights rights.

- You may freely distribute the URL identifying the publication in the public portal. please follow below link for the End User Agreement:

www.umlib.nl/taverne-license

Take down policy

If you believe that this document breaches copyright please contact us at:

repository@maastrichtuniversity.nl

providing details and we will investigate your claim.
}

Copyright and moral rights for the publications made accessible in the public portal are retained by the authors and/or other copyright owners and it is a condition of accessing publications that users recognise and abide by the legal requirements associated with these

- Users may download and print one copy of any publication from the public portal for the purpose of private study or research.

- You may not further distribute the material or use it for any profit-making activity or commercial gain

If the publication is distributed under the terms of Article $25 \mathrm{fa}$ of the Dutch Copyright Act, indicated by the "Taverne" license above, 
METHODIEK EN STRUCTUUR ARBEIDS-

MARKTMODULE I-SEE! 1991

ROA-W-1992/1

R.J.P. Dekker, A. de Grip, H. Berendsen

M.H. Wieling, E.J.T.A. Willems

RESEARCHCENTRUM VOOR ONDERWIJS EN ARBEIDSMARKT

Faculteit der Economische Wetenschappen

Rijksuniversiteit Limburg

Maastricht, februari 1992 
CIP-GEGEVENS KONINKLIJKE BIBLIOTHEEK, DEN HAAG

\section{Methodiek}

Methodiek en structuur arbeidsmarktmodule I-See! 1991 / R.J.P. Dekker... [et al.]. - Maastricht: Researchcentrum voor Onderwijs en Arbeidsmarkt, Faculteit der Economische Wetenschappen, Rijksuniversiteit Limburg. - (ROA-W, ISSN 0922-4645; 1992/1)

Met lit. opg.

ISBN 90-5321-088-1 in spiraalband

Trefw.: arbeidsmarkt; Nederland; toekomst / onderwijs en arbeidsmarkt ; Nederland ; toekomst. 


\section{INHOUDSOPGAVE}

VOORWOORD

1. INLEIDING

2. STRUCTUUR ARBEIDSMARKTINFORMATIE

3. ACTUELE DATA EN ARBEIDSMARKTINDICATOREN 4

3.1. Inleiding 4

3.2. Beroepsklasse-gegevens 5

3.3. Opleidingstype-gegevens 10

4. METHODIEK ARBEIDSMARKTPROGNOSES 14

4.1. Inleiding 14

4.2. De modellering van de uitbreidingsvraag $\quad 14$

$\begin{array}{ll}\text { 4.3. Methodiek vervangingsvraag } & 21\end{array}$

4.4. Methodiek arbeidsmarktinstroom van schoolverlaters 23

4.5. Typeringen van de prognoses $\quad 26$

4.6. Typering arbeidsmarktperspectieven 28

5. SCHEMATISCH OVERZICHT VAN DE ARBEIDSMARKTMODULE 31

5.1. Schermopbouw 31

5.2. Schermstructuur arbeidsmarktmodule 31

6. BESLUIT

$\begin{array}{ll}\text { LITERATUUR } & 35\end{array}$

BIJLAGE 1. TRANSFORMATIE VAN ARBEIDSMARKTINFORMATIE NAAR BEELD- 38 SCHERMTEKST 


\section{VOORWOORD}

In dit werkdocument wordt verslag gedaan van de activiteiten die zijn verricht om te komen tot de arbeidsmarktinformatie zoals die ten behoeve van het Information System on education and employment (I-See!) wordt aangeleverd. Het onderzoek is uitgevoerd door het Researchcentrum voor Onderwijs en Arbeidsmarkt (ROA) van de Rijksuniversiteit Limburg in opdracht van het Landelijk Dienstverlenend Centrum voor Studie- en Beroepskeuzevoorlichting (LDC). Belangrijke delen van de aan I-See! geleverde informatie zijn tevens weergegeven in het ROA-rapport 'De arbeidsmarkt naar opleiding en beroep tot 1994' en de bijbehorende statistische bijlage (zie ROA, 1992), dat is samengesteld in opdracht van het Ministerie van Onderwijs en Wetenschappen en het Centraal Bestuur voor de Arbeidsvoorziening.

Dit werkdocument sluit aan bij de eerder door het ROA uitgebrachte rapporten die betrekking hebben op I-See!: 'Inventariserend onderzoek arbeidsmarktmodule I-See! project' (De Grip, Heijke en Vos, 1987), 'De arbeidsmarktperspectieven van studierichtingen in het wetenschappelijk onderwijs 1992' (De Grip, Heijke, Dekker, Groot en Vos, 1987), 'Aanvulling arbeidsmarktmodule I-See! project' (De Grip, Heijke, Van Dam, Dekker en Wieling, 1988) 'De arbeidsmarktperspectieven van beroepsklassen en opleidingstypen in 1992: Rapportage I-See!' (De Grip, Heijke, Dekker, Beekman en Peeters, 1989) en Rapportage I-See! 1990 (Dekker, De Grip, Beekman, Van de Loo, Wieling en Willems, 1990).

De projectleiding van het I-See! onderzoek 1991 was in handen van dr. A. de Grip in samenwerking met drs. R.J.P. Dekker. Verder is aan het onderzoek meegewerkt door drs. Th.B.J. Beekman, drs. H. Berendsen, drs. M.H. Wieling en drs. E.J.T.A. Willems. P.W.T. Ghijsen en M.E.C. Reiners assisteerden bij de data-analyses. 


\section{INLEIDING}

Medio 1986 verleende het Ministerie van Onderwijs en Wetenschappen opdracht aan het Researchcentrum voor Onderwijs en Arbeidsmarkt (ROA) om een informatiesysteem onderwijsarbeidsmarkt te ontwikkelen. Dit systeem verstrekt informatie over de volle breedte van de arbeidsmarkt, verbijzonderd naar beroepsklassen en opleidingstypen.

Eén van de activiteiten van het ROA betreft de participatie in het I-See! project. Dit 'Information System on education and employment' is een geautomatiseerd informatiesysteem voor studieen beroepskeuze. De doelgroep van I-See! betreft in eerste instantie de intermediairs: schooldecanen, studie- en beroepskeuze-adviseurs en arbeidsbureaus. In I-See! wordt informatie verstrekt over meer dan 10.000 opleidingen en een duizendtal beroepen. Voor zowel beroepen als opleidingen wordt -op een hoger aggregatieniveau- op basis van de door het ROA aangeleverde gegevens ook arbeidsmarktinformatie gepresenteerd. De structuur van I-See! volgt deze driedeling in de verstrekte informatie door voor de desbetreffende beroepen-, opleidingenen arbeidsmarktgegevens aparte modules te onderscheiden. Tussen de drie modules zijn koppelingen aangebracht, zodat voor de eindgebruiker een transparant informatiesysteem ontstaat waarin deze driedeling in feite wordt opgeheven.

In dit werkdocument wordt een overzicht gegeven van de gehanteerde methodieken bij het samenstellen van de gegevens van de arbeidsmarktmodule van I-See!. Eerst wordt in hoofdstuk 2 de structuur van de in I-See! opgenomen arbeidsmarktinformatie besproken. In hoofdstuk 3 wordt vervolgens een beschrijving gegeven van de werkwijze waarlangs de actuele data en de arbeidsmarktindicatoren tot stand komen, waarna in hoofdstuk 4 wordt ingegaan op de methodiek die ten grondslag ligt aan de prognoses van de uitbreidingsvraag, de vervangingsvraag, de arbeidsmarktinstroom van schoolverlaters en de voor de nabije toekomst verwachte arbeidsmarktsituatie. Vervolgens komt in hoofdstuk 5 de vertaalslag van de aangeleverde gegevens naar de arbeidsmarktinformatie, zoals die op de beeldschermen van $1-$ See! wordt weergegeven, aan bod. Hoofdstuk 6 tenslotte, bevat een aantal conclusies over zowel het I-See! produkt en de arbeidsmarktinformatie, als ook ideeën om de methodieken voor het opstellen van de diverse prognoses te verbeteren. 


\section{STRUCTUUR ARBEIDSMARKTINFORMATIE}

Bij de constructie van de arbeidsmarktmodule dient als eerste een invulling te worden gegeven van de informatie die men wil opnemen en hoe deze informatie binnen I-See! wordt gepresenteerd. Daarnaast zal de indeling in beroepen en opleidingen binnen de arbeidsmarktmodule moeten aansluiten bij de te hanteren indelingen in respectievelijk de beroepen- en de opleidingenmodule.

Pere (1986) geeft een opsomming van een tiental kwantitatieve arbeidsmarktindicatoren die idealiter beschikbaar zouden moeten zijn voor de studie- of beroepskeuze:

- de ontwikkeling van de omvang van het beroepsdomein;

- het aandeel van het aantal werkenden binnen het domein in de totale beroepsbevolking;

- het aandeel van verschillende categorieën beroepsbeoefenaren in het desbetreffende domein;

- het opleidingsniveau en de opleidingsrichting van beroepsbeoefenaren;

- de mate van crisisgevoeligheid van het beroepsdomein;

- de leeftijdsopbouw van de beroepsbeoefenaren;

- de te verwachten ontwikkeling van het domein;

- de te verwachten instroom van arbeidskrachten naar het domein;

- mogelijke regionale verschillen in werkgelegenheid;

- de te verwachten discrepantie tussen vraag en aanbod in het beroepsdomein.

In deze opsomming gaat de meeste aandacht uit naar informatie met betrekking tot de op de arbeidsmarkt te onderscheiden beroepsdomeinen. Aan een beroepskeuze gaat echter doorgaans een meer of minder specifieke studiekeuze vooraf. De relatie tussen opleiding en beroep is weliswaar niet eenduidig, maar de keuze voor een bepaalde studie impliceert meestal wel een beperking in de mogelijke uit te oefenen beroepen. Om dit verband tussen opleiding en beroep weer te geven in de arbeidsmarktmodule van I-See!, moet de arbeidsmarktinformatie niet alleen betrekking hebben op opleidingen en beroepen, maar moeten er ook koppelingen tussen opleidingen en beroepen kunnen worden gemaakt. Bovendien is er, naast de behoefte aan actuele arbeidsmarktinformatie voor opleidingen en beroepen, een zeer grote rol weggelegd voor het in beeld brengen van de verwachte vraag- en aanbodontwikkelingen op de arbeidsmarkt.

In de arbeidsmarktmodule wordt hieraan voldaan door onderscheid te maken in beroepsklasseen opleidingstype-informatie, waarbij de informatie in beide gevallen bestaat uit actuele data en arbeidsmarktindicatoren enerzijds, en arbeidsmarktprognoses anderzijds. Tevens is er een 'doorsteekmogelijkheid' om de koppelingen tussen beroepsklassen en opleidingstypen te realiseren.

De diverse indicatoren en prognoses worden telkens op kwalitatieve wijze getypeerd. Voor de indicatoren is dit evident: een indicatorwaarde van 0,93 is op zich niet informatief, daarom wordt hieraan een typering (bijvoorbeeld 'erg hoog') gekoppeld. Ook aan de prognoses wordt een kwalitatieve typering toegevoegd, niet alleen vanwege eventuele interpretatieproblemen van een absolute uitkomst, maar vooral ook om schijnnauwkeurigheden te vermijden. Zo zou 
bijvoorbeeld een verwachte toekomstige werkgelegenheidsgroei van $5,1 \%$ als beter kunnen worden geïnterpreteerd dan een werkgelegenheidsgroei van 4,7\%, terwijl dit gezien de onzekerheidsmarges waarmee prognoses altijd zijn omgeven onterecht is.

Het is niet mogelijk om arbeidsmarktinformatie op hetzelfde aggregatieniveau te presenteren als in de opleidingen- en de beroepenmodule. De grootste beperking vormt de beschikbaarheid van de benodigde statistische gegevens. Van de algemene randvoorwaarden waaraan databronnen moeten voldoen om te worden opgenomen in het informatiesysteem onderwijs-arbeidsmarkt (zie Van Dam, De Grip en Heijke, 1988) zijn voor de I-See! gegevens met name de representativiteit en het over een langere periode beschikbaar zijn van de gegevens van belang. Dit leidt tot het noodgedwongen gebruiken van gegevens op een relatief hoog aggregatieniveau.

De belangrijkste bron van de voor I-See! gebruikte arbeidsmarktinformatie wordt gevormd door de gegevens van het Centraal Bureau voor de Statistiek (CBS). De door het CBS gehanteerde classificaties worden mede daarom ook door derden veel gebruikt, maar ook de vergelijkbaarheid met andere (internationale) coderingen vormt een pluspunt van de CBS-classificaties. Voor de classificatie van de opleidingen binnen I-See! wordt uitgegaan van de Standaard Onderwijs Indeling (SOI) van het CBS, waarbij opleidingen (op 5 digits) worden gecodeerd naar niveau, richting en vakrichting. Binnen de arbeidsmarktmodule vormt de 3-digit code van opleidingsniveau en -richting het uitgangspunt om te komen tot de uiteindelijke indeling in een vijftigtal opleidingstypen. Binnen de beroepenmodule van I-See! wordt de CBSberoepenclassificatie (4-digit) gehanteerd en deze beroepen worden binnen de arbeidsmarktmodule geaggregeerd tot 320 beroepsgroepen ( 3 digit) en 82 beroepsklassen ( 2 digit). De CBS-beroepsklassen blijken echter weinig geschikt voor gebruik ten behoeve van studie- en beroepskeuze. Om de kwaliteit van de in I-See! beschreven relatie opleiding-beroep en daarmee ook de relevantie van de gegeven arbeidsmarktinformatie naar beroep te verbeteren, heeft het ROA op basis van CBS-beroepsgroepen een eigen beroepenclassificatie ontwikkeld (Dekker, De Grip en Van de Loo, 1990). Daarin worden 93 beroepsklassen onderscheiden die zijn geconstrueerd op basis van een clustering van beroepsgroepen naar opleidingsachtergrond, hetgeen resulteert in een verbeterde koppeling tussen opleidingen en beroepen.

Tenslotte worden in I-See! nog twee overkoepelende begrippen onderscheiden, te weten voor beroepen het begrip bedrijfssector en voor opleidingen het begrip richting. Het richtingbegrip is in feite een bepaalde aggregatie van de diverse opleidingstypen. Bedrijfssector daarentegen is geen aggregatie van beroepen, maar een indeling van bedrijven op basis van de CBS Standaard BedrijfsIndeling (SBI). 


\section{ACTUELE DATA EN ARBEIDSMARKTINDICATOREN}

\subsection{Inleiding}

De arbeidsmarktmodule van I-See! verstrekt, zoals gezegd, arbeidsmarktinformatie voor zowel beroepen als opleidingen en vormt daarmee een logische aanvulling op de beroepen- en de opleidingenmodule van I-See!. De arbeidsmarktinformatie kan worden onderverdeeld in actuele data en arbeidsmarktindicatoren enerzijds en arbeidsmarktprognoses anderzijds. In dit hoofdstuk zal worden ingegaan op de vertaalslag van actuele data en arbeidsmarktindicatoren voor beroepsklassen en opleidingstypen naar kwalitatieve typeringen.

Met betrekking tot de data kan thans gebruik worden gemaakt van recente gegevens uit de Enquête Beroepsbevolking (EBB). Bij de beroepsklassen kan voor de actuele data en arbeidsmarktindicatoren gebruik worden gemaakt van de EBB 1988, 1989 en 1990, zodat ook de 'trendmatige' ontwikkeling op basis van de EBB kan worden bepaald. Voor de vereiste arbeidsmarktinformatie voor opleidingstypen zijn tot nu toe alleen gegevens uit de EBB 1990 beschikbaar, zodat er voor de trendmatige ontwikkeling nog steeds moet worden teruggevallen op de data van de Arbeidskrachtentelling (AKT) die voor het laatst in 1985 is gehouden.

Het koppelen van AKT- en EBB-gegevens is geen eenvoudige opgave vanwege de trendbreuk tussen de twee enquêtes: de EBB telt ongeveer éen miljoen werkzame personen meer dan de $A K T$, hetgeen naast de feitelijke groei van de werkgelegenheid ook voortvloeit uit het feit dat in de EBB meer deeltijd-werkers zijn opgenomen. Vanaf volgend jaar gaat het CBS een nieuwe definitie van werkzame bevolking toepassen (een minimale arbeidstijd van 12 uur per week, zie Bierings, Bochove en Imbens, 1990). Dit zal leiden tot een daling van het absolute aantal werkzame personen, waardoor er weer een breuk zal optreden met de huidige gegevens. De trendbreuk in de beschikbare data maakt dat er een grote claim komt te liggen op het consistent maken van de EBB-gegevens voor beroepsklassen (1988-'91) en voor opleidingstypen (1990'91).

Voor de EBB-gegevens geldt een ondergrens op de aantallen in de tabellen van 5.000 werkenden voor het publiceren van de gegevens. Voor een aantal kleine beroepsklassen voldoet het aantal werkenden niet aan deze ondergrens en wordt teruggevallen op de wel beschikbare AKT-gegevens. Deze kleine beroepsklassen kunnen in de toekomst wel worden gepresenteerd indien er in plaats van EBB-jaarcijfers gebruik kan worden gemaakt van gemiddelden over een aantal jaren. De ondergrens met betrekking tot publikatie daalt dan namelijk van 5.000 naar 2.000 .

Deze overgang van AKT naar EBB voor de basisgegevens leidt, zoals hierboven reeds is aangegeven, tot verschillende berekeningswijzen van de trendmatige ontwikkeling van de historische gegevens per beroepsklasse en opleidingstype. Voor de trendmatige ontwikkeling van opleidingstypen is vooralsnog gebruik gemaakt van de AKT-gegevens en de formule voor de trend is daarmee ook dezelfde gebleven: 
Trend $=\frac{\text { Data ' } 83+\text { Data '85 }}{\text { Data } 79+\text { Data ' } 81}$

Voor beroepsklasse- en beroepsgroepgegevens ${ }^{1}$ wordt de trendmatige ontwikkeling als volgt bepaald:

Trend $=\frac{\text { Data ' } 89+\text { Data ' } 90}{\text { Data' } 88+\text { Data '89 }}$

De grenzen voor de typering van de trend zijn in beide gevallen dezelfde:

Typering trend $(T)$ :

\begin{tabular}{|c|c|c|c|c|c|}
\hline & & T & $\leq$ & 0,80 & sterk dalend \\
\hline 0,80 & $<$ & $T$ & $\leq$ & 0,95 & dalend \\
\hline ,95 & $<$ & $\mathrm{T}$ & $\leq$ & 1,05 & constant \\
\hline 1,05 & $<$ & $\mathrm{T}$ & $\leq$ & 1,20 & stijgend \\
\hline 20 & $<$ & $\mathrm{T}$ & & & sterk stijgenc \\
\hline
\end{tabular}

\subsection{Beroepsklasse-gegevens}

In de arbeidsmarktmodule worden voor de beroepsklassen de volgende actuele data en arbeidsmarktindicatoren weergegeven:

\section{Actuele data:}

- Aantal werkenden

* gemiddeld aantal werkenden, percentage in totaal aantal werkenden, typering en trend

* gemiddeld percentage zelfstandigen, typering en trend

- Leeftijdsopbouw

* gemiddeld percentage 15 tot 30 jarigen en trend

* gemiddeld percentage 30 tot 40 jarigen en trend

* gemiddeld percentage 40 tot 50 jarigen en trend

* gemiddeld percentage 50 tot 65 jarigen en trend

* typering van de leeftijdsopbouw

- Vooropleiding

* gemiddeld percentage basisonderwijs en trend

* gemiddeld percentage mavo-ers en trend

* gemiddeld percentage havo/vwo-ers en trend

1. De kruistabellen beroepsklasse-opleidingstype en beroepsgroep-opleidingstype (de zgn. 'hangmatten') zijn vooralsnog bepaald op basis van AKT-data, omdat de celvulling van de laatstgenoemde tabel op basis van EBB-data te gering is. Omwille van de consistentie in de gegevens is de hangmat beroepsklasse-opleidingstype op dezelfde AKT-cijfers bepaald. 
* gemiddeld percentage lbo-ers en trend

* gemiddeld percentage mbo-ers en trend

* gemiddeld percentage hbo-ers en trend

* gemiddeld percentage wo-ers en trend

* typering van de vooropleiding

- Bedrijfssectorinformatie binnen de beroepsklasse

* gemiddeld percentage werkenden naar bedrijfssector en trend

- Opleidingstype-informatie binnen de beroepsklasse

* gemiddeld percentage werkenden naar opleidingstype en trend

- Opleidingstype-informatie binnen de beroepsgroep

* gemiddeld percentage werkenden naar opleidingstype en trend

- Beroepsgroepinformatie binnen de beroepsklasse

* gemiddeld aantal werkenden, percentage, typering en trend

* gemiddeld percentage vrouwen, typering en trend

* gemiddeld percentage deeltijders $(\leq 30$ uur), typering en trend

Het gemiddelde heeft daarbij telkens betrekking op het gemiddelde over de jaren waarvoor de gegevens beschikbaar zijn.

Arbeidsmarktindicatoren:

- Branchespreiding per beroepsklasse

* typering en trend

- Conjunctuurgevoeligheid beroepsklasse

* typering

Vanwege de overgang naar een nieuwe beroepsklasse-indeling en het gebruik van de EBB zijn de kwalificaties ten opzichte van de vorige versie (Dekker, De Grip, Beekman, Van de Loo, Wieling en Willems, 1990) aangepast volgens de symmetrische, de kwantielen- of de ad-hoc methode die in Wieling, De Grip en Willems (1990) uitvoerig wordt beschreven.

In het onderstaande wordt voor de actuele data en de arbeidsmarktindicatoren de grenzenindeling die bij de typering is gehanteerd weergegeven. Voor ieder onderdeel wordt daarbij een korte toelichting gegeven:

Het percentage en absolute aantal werkenden geeft informatie over de (relatieve) omvang van het huidige werkveld. De cijfers zijn ontleend aan de EBB (1988-'90) voorzover aan de ondergrenzen is voldaan. Voor informatie die hier niet aan voldoet is teruggevallen op de AKT (1979-'85). De typering vindt plaats op het percentage werkenden, dat een gemiddelde is over de jaren 1988-' 90. 
Typering percentage werkenden (BW):

\begin{tabular}{|c|c|c|c|c|c|}
\hline & & BW & $\leq$ & 0,15 & erg laag \\
\hline, 15 & $<$ & BW & $\leq$ & 0,40 & laag \\
\hline 40 & $<$ & BW & $\leq$ & 0,90 & hidd \\
\hline 90 & $<$ & BW & $\leq$ & 2,60 & hoog \\
\hline 60 & $<$ & BW & & & erg hoog \\
\hline
\end{tabular}

Het percentage zelfstandigen is bepaald op basis van de EBB-gegevens, waarbij voor kleine beroepsklassen is teruggevallen op de AKT-gegevens. De presentatie van het percentage zelfstandigen in de huidige vorm levert echter weinig aanvullende informatie. Immers bij de beroepsklasse 'zelfstandige winkeliers' kan men uit de naam ook wel afleiden dat het percentage zelfstandigen $100 \%$ is, maar om binnen de relatief kleine beroepsklasse 'accountants' het percentage zelfstandigen te presenteren moet momenteel worden teruggevallen op AKT-data uit 1985.

Typering percentage zelfstandigen (Z):

$\begin{array}{rllll} & Z & = & 0 & \text { erg laag } \\ 0 & <Z & \leq & 10 & \text { laag } \\ 10<Z & \leq & 20 & \text { gemiddeld } \\ 20<Z & \leq & 50 & \text { hoog } \\ 50 & <Z & & & \text { erg hoog }\end{array}$

De indeling van de leeftijdsklassen is ten opzichte van eerdere I-See! versies veranderd om te komen tot een meer evenwichtige verdeling van de werkzame personen over de leeftijdsgroepen: de categorieën 50 tot 60 jaar en 60 tot 65 jaar zijn samengenomen, waardoor de leeftijdsindeling er nu als volgt uit ziet: tot 30 jaar, van 30 tot 40 jaar, van 40 tot 50 jaar en van 50 tot 65 jaar. Daarnaast wordt in I-See! een kwalitatieve typering gegeven van de gemiddelde leeftijd van de werkenden in een beroepsklasse.

Typering leeftijdsopbouw (L):

\begin{tabular}{|c|c|c|c|c|c|}
\hline & & L & $\leq$ & 29 & erg laag \\
\hline 29 & $<$ & L & $\leq$ & 33 & laag \\
\hline 33 & $<$ & L & $\leq$ & 38 & gemiddeld \\
\hline 38 & $<$ & L & $\leq$ & 42 & hoog \\
\hline 42 & $<$ & $\mathrm{L}$ & $\leq$ & 65 & erg hoog \\
\hline
\end{tabular}

Bij de beroepsklassen wordt in twee stappen informatie gegeven over de opleidingsachtergrond van de werkzame personen in het desbetreffende beroep. In de eerste stap worden zeven opleidingscategorieën onderscheiden: basisonderwijs, mavo, havo/vwo, lager beroepsonderwijs, middelbaar beroepsonderwijs, hoger beroepsonderwijs en wetenschappelijk onderwijs. Per beroepsklasse wordt dan de procentuele verdeling van de werkzame personen over deze opleidingscategorieën weergegeven. Evenals bij de leeftijdsopbouw is het niet zinvol om voor elk aandeel van een bepaald opleidingstype in de beroepsklasse een kwalitatieve typering te geven, 
omdat het hier om het totaalbeeld gaat. Wel is op basis van de onderscheiden opleidingsniveaus het gemiddelde aantal jaren gevolgd onderwijs per beroepsklasse geschat. Voor de bepaling van dit gemiddelde is aangesloten bij de Standaard Onderwijs Indeling waarin het basisonderwijs wordt gelijk gesteld op 6 jaar onderwijs, het mavo en lbo op 9 jaar, het havo/vwo en mbo op 12 jaar, het hbo op 15 jaar en het wo op 18 jaar. Dit gemiddelde wordt telkens omgezet in een kwalitatieve typering.

Typering vooropleiding (VO):

\begin{tabular}{|c|c|c|c|c|c|}
\hline & & Vo & $\leq$ & 8 & erg laag \\
\hline 8 & $<$ & Vo & $\leq$ & 10 & laag \\
\hline 10 & $<$ & Vo & $\leq$ & 12 & gemiddelo \\
\hline 12 & $<$ & Vo & $\leq$ & 15 & hoog \\
\hline 15 & $<$ & vo & $\leq$ & 18 & erg hoog \\
\hline
\end{tabular}

In de tweede stap sluit de indeling van opleidingen aan bij de ROA-opleidingstypen die in de arbeidsmarktmodule worden onderscheiden. Per beroepsklasse wordt aangegeven welke opleidingsachtergrond de werkenden hebben. Op het lagere aggregatieniveau van beroepsgroep wordt eveneens een opsomming gegeven van de daarin aanwezige opleidingstypen.

Voor de beroepsklassen wordt op analoge wijze als bij de koppeling beroepsklasseopleidingstype een verband gelegd naar bedrijfssectoren. Per beroepsklasse wordt aangegeven in welke bedrijfssectoren de werkenden zich bevinden. Vanwege het feit dat er nu geen samenvattende grootheid (er bestaat geen gemiddeld bedrijfssector-niveau) kan worden bepaald, wordt in I-See! volstaan met het vermelden van de percentages en de trendmatige ontwikkeling.

Bij de overzichten van de belangrijkste opleidingstypen en bedrijfssectoren per beroepsklasse worden in verband met de betrouwbaarheid en hanteerbaarheid van de informatie alleen die opleidingen en sectoren genoemd waarvoor het percentage werkenden minimaal $1 \%$ is. Bij een percentage van minimaal $5 \%$ wordt naast de naam van het opleidingstype of de bedrijfssector ook het percentage en de trend gepresenteerd.

Op beroepsgroepniveau wordt een drietal kengetallen gepresenteerd: aantal werkenden, percentage vrouwen en percentage werkenden in deeltijd ${ }^{2}$. Met name voor de beroepsgroepen geldt dat de gegevens beneden de ondergrenzen kunnen komen die het CBS stelt voor publikatie. Derhalve is voor de beroepsgroepen met minder dan 5.000 werkenden voor het genereren van de arbeidsmarktinformatie gebruik gemaakt van de AKT. Voor I-See! dient immers voor elke onderscheiden beroepsgroep dezelfde soort informatie te worden gepresenteerd. Met betrekking tot de ondergrenzen voor publikatie van EBB-gegevens geldt ook hier dat door de rechtstreekse berekening van jaargemiddelden in de toekomst lagere

2. Het percentage deeltijders is gedefinieerd als het aandeel werkenden dat 30 uur of minder per week werkt. 
$-9-$

ondergrenzen gehanteerd kunnen worden, zodat de (verouderde) AKT-gegevens niet meer nodig zijn.

Typering aantal werkenden per beroepsgroep (BGR):

$\begin{array}{rlrl} & & B G R \leq & 1.000 \text { erg laag } \\ 1.000 & <B G R \leq & 4.000 \text { laag } \\ 4.000 & <B G R \leq & 12.000 \text { gemiddeld } \\ 12.000 & <B G R \leq & 30.000 \text { hoog } \\ 30.000 & <\text { BGR } & \text { erg hoog }\end{array}$

Typering percentage vrouwen per beroepsgroep (V):

\begin{tabular}{|c|c|c|c|c|c|}
\hline & & V & $\leq$ & 0,5 & erg laag \\
\hline 0,5 & $<$ & V & $\leq$ & 5 & laag \\
\hline 5 & $<$ & V & $\leq$ & 20 & gemiddel \\
\hline & $<$ & v & $\leq$ & 50 & hoog \\
\hline & $<$ & v & & & erg hoog \\
\hline
\end{tabular}

Typering percentage deeltijders per beroepsgroep (D):

\begin{tabular}{|c|c|c|c|c|c|}
\hline & & $D$ & $\leq$ & 0,5 & erg laag \\
\hline 0,5 & $<$ & D & $\leq$ & 5 & laag \\
\hline 5 & $<$ & D & $\leq$ & 10 & gemidde \\
\hline & $<$ & $D$ & $\leq$ & 20 & hoog \\
\hline & $<$ & $D$ & & & erg hoog \\
\hline
\end{tabular}

De conjunctuurgevoeligheid voor beroepsklassen wordt bepaald door de fluctuatie-index per bedrijfssector te wegen met het aandeel van een bedrijfstak in de werkgelegenheid van de desbetreffende beroepsklasse (zie ook De Grip en Heijke, 1988):

$C I_{b}=\sum_{s=1}^{S}\left(\frac{W P_{b s}}{W P_{b}}\right) \cdot\left(\frac{100}{H} \sum_{t=1}^{H} \frac{\left|F_{s t}\right|}{T_{s t}}\right)$

$\mathrm{Cl}_{\mathrm{b}} \quad=$ Conjunctuurindicator voor beroepsklasse $\mathrm{b}$;

$\mathrm{WP}_{\mathrm{bs}} \quad=$ Aantal werkenden in beroepsklasse $\mathrm{b}$ en bedrijfssector s (in 1990);

$W P_{b} \quad=$ Aantal werkenden in beroepsklasse $b$ (in 1990);

$\mathrm{S} \quad=$ Aantal bedrijfssectoren;

$\mathrm{F}_{\mathrm{st}} \quad=\left(\mathrm{WP}_{\mathrm{st}}-\mathrm{T}_{\mathrm{st}}\right)=$ afwijking van de trendmatige werkgelegenheidsontwikkeling in bedrijfssector $s$ op tijdstip t;

$\mathrm{T}_{\mathrm{st}} \quad=$ Trendmatige werkgelegenheidsontwikkeling in bedrijfssector $\mathrm{s}$ op tijdstip $\mathrm{t}$;

$\mathrm{H} \quad=$ Aantal waarnemingsjaren (1950-1988).

De conjunctuurindex geeft informatie over de mate van werkzekerheid in een beroepsklasse als gevolg van conjuncturele fluctuaties van de werkgelegenheid in de bedrijfssectoren. Voor een beroepsklasse met een hoge conjunctuurgevoeligheid is de kans op een sterke omslag van de werkgelegenheidsontwikkeling op de lange termijn gezien groter. 
Typering conjunctuurindicator (Cl):

$\begin{aligned} & \mathrm{Cl} \leq 1,00 \text { erg laag } \\ & 1,00<\mathrm{Cl} \leq 1,45 \text { laag } \\ & 1,45<\mathrm{Cl} \leq 2,15 \text { gemiddeld } \\ & 2,15<\mathrm{Cl} \leq 2,60 \text { hoog } \\ & 2,60<\mathrm{Cl}\end{aligned}$

De bedrijfssectorspreiding is een indicatie van de uitwijkmogelijkheden van een beroepsklasse over de verschillende bedrijfssectoren en wordt bepaald middels de formule van Gini-Hirschman (zie Sheldon, 1985, Warnken, 1986 en De Grip, Van der Velden en Wieling, 1991):

$B S_{b}=\left(1-\sum_{s=1}^{S}\left(\frac{W P_{b s}}{W P_{b}}\right)^{2}\right) \cdot \frac{S}{(S-1)}$

$\mathrm{BS}_{\mathrm{b}}=$ Bedrijfssectorspreiding voor beroepsklasse $\mathrm{b}$;

$W P_{b s}=$ Aantal werkenden in beroepsklasse $b$ en bedrijfssector $s$;

$W P_{b}=$ Aantal werkenden in beroepsklasse $b$;

$\mathrm{S} \quad=$ Aantal bedrijfssectoren.

Een hoge coëfficiënt duidt op veel uitwijkmogelijkheden, waardoor de werkgelegenheidsontwikkeling in de beroepsklasse niet, of minder afhankelijk is van de ontwikkelingen in én specifieke bedrijfssector. De typering van de branchespreiding wordt bepaald op basis van een gemiddelde over de EBB-jaren 1988-' 90.

Typering branchespreiding per beroepsklasse (BS):

\begin{tabular}{|c|c|c|c|c|}
\hline & & $\mathrm{BS} \leq$ & 0,25 & erg laag \\
\hline, 25 & $<$ & $B S \leq$ & 0,45 & laag \\
\hline 0,45 & $<$ & $\mathrm{BS} \leq$ & 0,75 & gemiddeld \\
\hline 0,75 & $<$ & $\mathrm{BS} \leq$ & 0,95 & hoog \\
\hline O & & BS & & erg hoog \\
\hline
\end{tabular}

\subsection{Opleidingstype-gegevens}

In de arbeidsmarktmodule van I-See! zijn voor alle onderscheiden ROA-opleidingstypen de volgende actuele data en arbeidsmarktindicatoren opgenomen:

Actuele data:

- Aantal werkenden

* gemiddeld aantal werkenden, percentage in totaal aantal werkenden, typering en trend

- Werklozen

* werkloosheidspercentage, typering en trend

* werkloosheidspercentage onder schoolverlaters en typering

* regionale werkloosheidstyperingen (voor avo-, lbo- en mbo-opleidingen) 
- Beroepsklasse-informatie binnen het opleidingstype

* gemiddeld percentage werkenden in de beroepsklassen en trend

- Beroepsgroep-informatie binnen het opleidingstype

* gemiddeld percentage werkenden in de beroepsgroepen en trend

\section{Arbeidsmarktindicatoren:}

- Branchespreiding

* typering en trend

- Beroepenspreiding

* typering en trend

Het percentage en het absolute aantal werkenden geeft informatie over de grootte van het huidige werkveld van het desbetreffende opleidingstype. De cijfers zijn ontleend aan de EBB 1990 voorzover aan de CBS-ondergrenzen is voldaan. Voor informatie die hier niet aan voldoet en voor de bepaling van de trendmatige ontwikkeling is gebruik gemaakt van AKT-cijfers (1979'85).

Typering percentage werkenden (OW):

$$
\begin{gathered}
\text { OW } \leq 0,10 \text { erg laag } \\
0,10<O W \leq 0,35 \text { laag } \\
0,35<O W \leq 1,50 \text { gemiddeld } \\
1,50<O W \leq 4,50 \text { hoog } \\
4,50<O W \quad \text { erg hoog }
\end{gathered}
$$

Het percentage werklozen heeft betrekking op het standcijfer van half april 1991. Het bronbestand is het bemiddelingsbestand zonder baan van de Arbeidsvoorzieningsorganisatie. Vanwege het nog niet bekend zijn van de werkzame personen in 1991 worden de als werkloos getypeerde ingeschrevenen in april 1991 gerelateerd aan de werkzame personen in 1990 en de werklozen 1991. Ondanks de onnauwkeurigheid van deze data, door de bestandsvervuiling en de gedeeltelijk tekortschietende codering van de opleidingsgegevens, wordt waarschijnlijk toch een redelijke indicatie gegeven van de ernst van de werkloosheidsproblematiek voor de desbetreffende groep in vergelijking tot andere groepen. Daarnaast wordt ook een indicatie gegeven van de werkloosheid onder schoolverlaters. In tegenstelling tot de eerdere versies van I-See!, wordt nu niet het aandeel van de schoolverlaters in de werkloosheid gegeven, maar het percentage werkloze schoolverlaters inclusief een kwalitatieve typering van dit percentage. De typeringen voor werklozen en werkloze schoolverlaters zijn gebaseerd op verschillende schaalindelingen vanwege de relatief hoge werkloosheid onder de schoolverlaters. Indien de werkloosheid onder schoolverlaters hoger is dan het algemene werkloosheidspercentage dan kan dit duiden op problemen met betrekking tot arbeidsmarktintrede voor een bepaald opleidingstype, zeker als wordt meegenomen dat in de bepaling van het algehele werkloosheidspercentage ook de langdurig werklozen worden meegeteld. Immers, na bijna een jaar na het verlaten van de school (de meting vindt plaats in april) mag worden verwacht dat de 
werkloosheid onder schoolverlaters overeenkomt met het algemene beeld. Een lager werkloosheidspercentage onder de schoolverlaters duidt op betere intredemogelijkheden dan voor de gehele populatie met een bepaald opleidingstype.

Typering werkloosheidspercentage (W):

$\begin{array}{rlll} & W & \leq 1 & \text { erg laag } \\ 1<W & \leq 3 & \text { laag } \\ 3<W & \leq 7 & \text { gemiddeld } \\ 7<W & \leq 10 & \text { hoog } \\ 10<W & & & \text { erg hoog }\end{array}$

Typering werkloosheidspercentage schoolverlaters (WS):

\begin{tabular}{|c|c|c|c|c|}
\hline & WS & $\leq$ & 2 & erg laag \\
\hline $2<$ & WS & $\leq$ & 4 & laag \\
\hline $4<$ & ws & $\leq$ & 10 & gemiddeld \\
\hline $10<$ & WS & $\leq$ & 30 & hoog \\
\hline $30<$ & WS & & & erg hoog \\
\hline
\end{tabular}

Voor de trendbepaling van de werkloosheid is de werkloosheid in april 1991 vergeleken met de werkloosheid in april $1990^{3}$, waarbij is gecorrigeerd voor de relatief grote restgroepen die ontstaan doordat bij een relatief groot aantal werklozen door de arbeidsbureaus niet exact achterhaald is welke opleiding de werkloze heeft gevolgd (vaak is alleen het opleidingsniveau bekend). Vanwege de afwijkende interpretatie en berekening van deze trend ten opzichte van de elders in de arbeidsmarktmodule gebruikte trend-typeringen is voor de trend-typering van de werkloosheid een aparte indeling gebruikt.

Typering trend werkloosheidspercentage (TW):

$$
\begin{aligned}
& \mathrm{TW} \leq 0,70 \text { sterk dalend } \\
0,70<\mathrm{TW} & \leq 0,90 \text { dalend } \\
0,90<\mathrm{TW} & \leq 1,10 \text { constant } \\
1,10<\mathrm{TW} & \leq 1,30 \text { stijgend } \\
1,30<\mathrm{TW} & \text { sterk stijgend }
\end{aligned}
$$

In de huidige versie van I-See! is voor het eerst regionale informatie opgenomen. De werkloosheidscijfers zijn voor de opleidingstypen tot en met het mbo uitgesplitst naar de 28 RBA-gebieden. Voor het hbo en het wo worden geen regionale werkloosheidscijfers gegeven, omdat voor deze opleidingen in feite een landelijke arbeidsmarkt bestaat ${ }^{4}$.

3. De periode voor de bepaling van de trend bedraagt slechts twee jaar omdat het percentage werklozen alleen voor 1990 en 1991 kan worden bepaald. Voor eerdere jaren is slechts het percentage 'ingeschrevenen' beschikbaar.

4. Zie voor een uitgebreid overzicht Wieling, Dekker en De Grip (1991). 
Ook voor opleidingstypen is het mogelijk om dwarsverbanden met beroepsklassen en beroepsgroepen te leggen. Voor elk opleidingstype wordt een overzicht gegeven van de belangrijkste beroepsklassen en beroepsgroepen waarin men met de desbetreffende opleiding is terecht gekomen. In de desbetreffende overzichten wordt de naam van de beroepsklasse c.q. groep alleen weergegeven als het aandeel van het desbetreffende beroep minimaal $1 \%$ is en het percentage en de trend-typering worden slechts weergegeven als het percentage minimaal $5 \%$ is.

Voor opleidingstypen zijn net als voor beroepsklassen spreidingsmaatstaven geconstrueerd. Naast de branchespreiding is nu tevens de beroepenspreiding per opleidingstype bepaald. De laatste grootheid geeft aan hoe groot de spreiding van het opleidingstype over de diverse beroepsklassen is. De branche- en beroepenspreiding voor opleidingstypen worden als volgt getypeerd $^{5}$ :

Typering branchespreiding per opleidingstype (OS):

$\begin{aligned} & \text { OS } \leq 0,55 \text { erg laag } \\ & 0,55<O S \leq 0,70 \text { laag } \\ & 0,70<O S \leq 0,85 \text { gemiddeld } \\ & 0,85<O S \leq 0,95 \text { hoog } \\ & 0,95<O S \leq \text { erg hoog }\end{aligned}$

Typering beroepenspreiding per opleidingstype (OB):

\begin{tabular}{|c|c|c|c|c|c|}
\hline & & OB & $\leq$ & 0,70 & erg laag \\
\hline 0,70 & $<$ & OB & $\leq$ & 0,80 & laag \\
\hline 0,80 & $<$ & OB & $\leq$ & 0,90 & jemiddelc \\
\hline 0,90 & $<$ & OB & $\leq$ & 0,95 & hoog \\
\hline 95 & $<$ & OB & $\leq$ & & erg hoog \\
\hline
\end{tabular}

5. De formules voor de branche- en beroepenspreiding voor opleidingstypen zijn analoog aan formule 3.4, de branchespreiding per beroepsklasse. 


\section{METHODIEK ARBEIDSMARKTPROGNOSES}

\subsection{Inleiding}

In dit hoofdstuk wordt een korte toelichting gegeven op de totstandkoming van de verschillende prognoses van de arbeidsmarktperspectieven van opleidingstypen en de vertaalslag naar de kwalitiatieve typering $^{6}$. Binnen het ROA-informatiesysteem onderwijs-arbeidsmarkt is gekozen voor de 'stroomcijfer'-aanpak. In plaats van een prognose van de situatie op een bepaald toekomstig tijdstip wordt een prognose gemaakt van de situatie gedurende een bepaalde toekomstige periode. De prognoses hebben, evenals de actuele data en arbeidsmarktindicatoren, betrekking op beroepsklassen en opleidingstypen verdeeld over de volle breedte van de arbeidsmarkt. Eerst zal achtereenvolgens de methodiek voor de uitbreidingsvraag, de vervangingsvraag en de prognose van de toekomstige instroom van schoolverlaters op de arbeidsmarkt worden besproken. Daarna wordt ingegaan op de schaalindelingen die ten grondslag liggen aan de uiteindelijke kwalitatieve typeringen van de verschillende prognoses. Tenslotte wordt een toelichting gegeven op de totstandkoming van de typering van de (samenvattende) arbeidsmarktperspectieven per opleidingstype.

\subsection{De modellering van de uitbreidingsvraag}

Voor zowel beroepsklassen als opleidingstypen worden prognoses opgesteld van de werkgelegenheidsontwikkeling in de periode 1989-1994. Deze periode komt overeen met de prognoseperiode van de middellange-termijnraming van het Centraal Planbureau (CPB). In de toekomst zal er naar worden gestreefd in principe 5 jaar vooruit te voorspellen, hetgeen beter overeenkomt met de tijd die er doorgaans ligt tussen het moment van studiekeuze en het tijdstip waarop men zich voor het eerst op de arbeidsmarkt aanbiedt.

De werkgelegenheidsprognose start in feite bij het opstellen van bedrijfstakprognoses van de werkgelegenheidsontwikkeling. Hiervoor wordt gebruik gemaakt van de prognoses van de werkgelegenheidsontwikkeling per bedrijfssector van het CPB. Dit heeft als voordeel dat de door ons opgestelde prognoses naar opleiding en beroep consistent zijn met de macro- en mesoeconomische prognoses van het CPB. Bovendien kan op deze wijze de aandacht volledig worden gericht op het modelleren van de uitbreidingsvraag voor beroepen en opleidingen.

In figuur 1 staat aangegeven hoe de prognoses van de werkgelegenheids-ontwikkeling voor beroepen en opleidingen tot stand komen. Vanuit de bedrijfstakprognose wordt een prognose opgesteld voor de diverse (ROA-)beroepssegmenten. Deze 48 segmenten zijn een aggregatie van de in I-See! gebruikte beroepsklassen (zie Dekker, De Grip en Van de Loo, 1990). Door de analyse uit te voeren op deze beroepssegmenten in plaats van op de meer gedesaggregeerde beroepsklassen, zoals in het verleden gebeurde, neemt de celvulling en daarmee de

6. Voor alle prognoses geldt overigens dat er aparte werkdocumenten zijn verschenen waarin dieper op de gebruikte technieken wordt ingegaan. 
betrouwbaarheid van de schattingen toe. Vanuit de werkgelegenheidsprognoses per beroepssegment vindt er een verdere uitsplitsing plaats naar enerzijds de prognose per beroepsklasse en anderzijds de prognose naar opleidingstype. In het opleidingenmodel wordt eerst een schatting gemaakt van de werkgelegenheidsontwikkeling van de verschillende opleidingsrichtingen. Daarna wordt elke richting opgesplitst naar niveau, waarna de opleidingsniveaus en -richtingen tenslotte verder worden verbijzonderd naar de uiteindelijke 49 opleidingstypen die in I-See! worden onderscheiden.

Figuur 1. Overzicht van de modellering van de uitbreidingsvraag

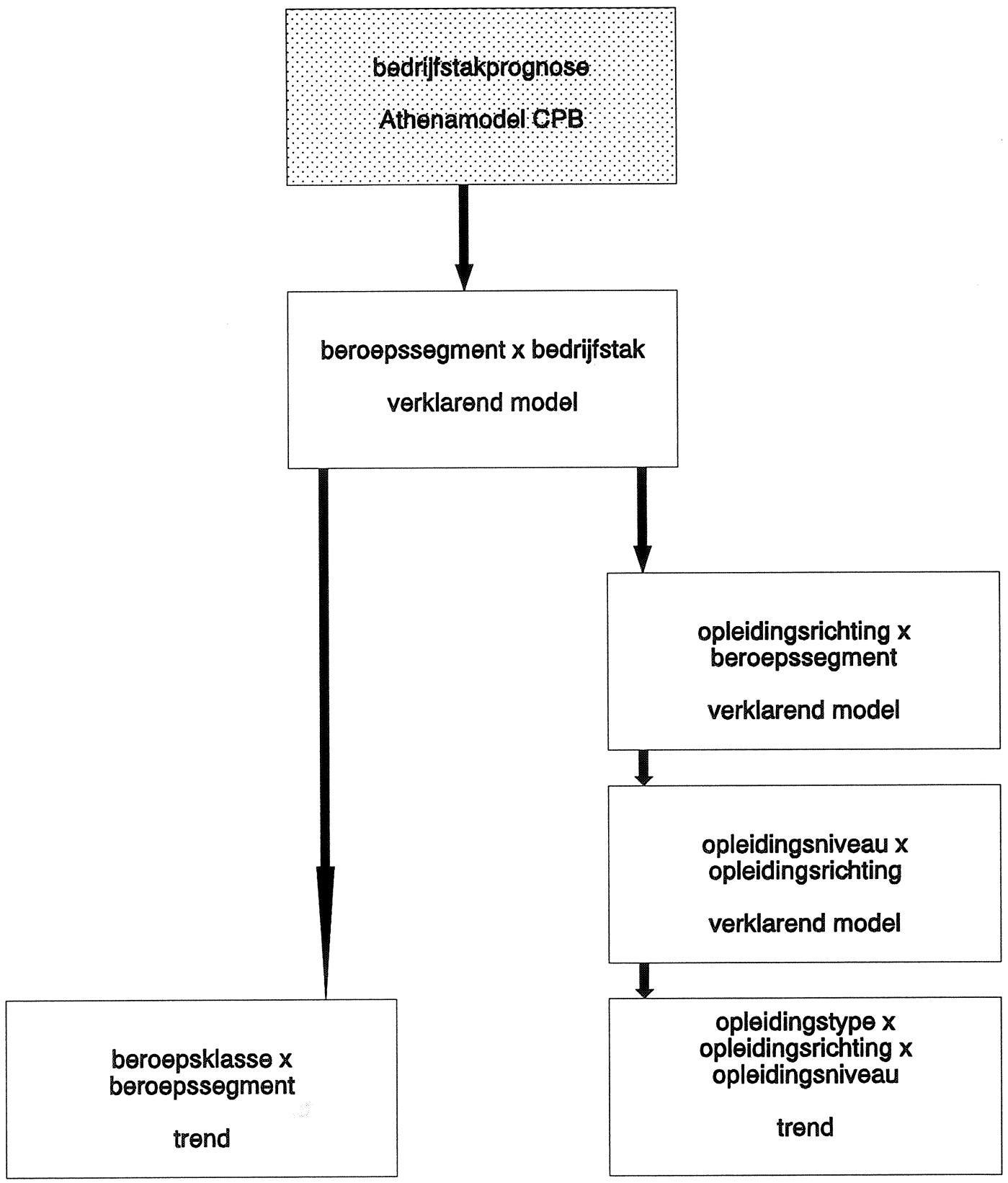


De AKT's vormen nog steeds de basisgegevens waarop de schattingen zijn uitgevoerd. Voor toekomstige modellen zal evenwel gebruik worden gemaakt van datamateriaal uit zowel de AKT- als de EBB-bestanden?.

\section{Het beroepenmodel}

Bij de constructie van het beroepenmodel is uitgegaan van de veronderstelling dat de beroepenstructuur van de werkgelegenheid door de vraagzijde van de arbeidsmarkt wordt bepaald ${ }^{8}$. Getracht is deze vraagkant in beeld te brengen door het opstellen van een aantal uit de economische theorie af te leiden factoren, die de beroepenstructuur beïnvloeden.

De technologische ontwikkeling is een van de belangrijkste factoren, waarvan de relevantie in het beroepenmodel nader wordt onderzocht. De beroepenstructuur kan eveneens beïnvloed worden door de conjunctuurfase waarin een bedrijfstak verkeert. Zeker op de secundaire arbeidsmarkt zal de conjunctuur sterker doorwerken op de werkgelegenheid, dan op de primaire arbeidsmarkt, waarvoor bij conjuncturele neergang eerder het aantonen van een arbeidsreserve binnen het bedrijf (labour hoarding) wordt verwacht (De Koning, 1987).

In deze opsomming ontbreekt de invloed van de loonkosten op de werkgelegenheidsstructuur. De reden hiervoor is dat goede data met betrekking tot de ontwikkeling van de loonkosten op gedesaggregeerd niveau ontbreken. Impliciet wordt derhalve de veronderstelling gemaakt dat de loonstructuur zelf niet verandert, of dat de invloed van de loonstructuur op de werkgelegenheidsstructuur constant is. Voor de andere economische factoren zijn wel variabelen beschikbaar, waarmee de effecten op de beroepenstructuur kunnen worden gemeten.

Voor het weergeven van de technologische ontwikkeling worden de reële investeringen in outillage, transport en grond-, weg- en waterbouwkundige werken gerelateerd aan de sectorale werkgelegenheid. Beide gegevens zijn afkomstig van het CPB.

$I N V A R B_{s t}=\left[\sum_{h=-9}^{0} I N V_{s t+h}\right]\left[\left[\sum_{h=-2}^{2} A R B_{s t+h} / 5\right]\right.$

INVARB $_{\text {st }}=$ Indicator technologische ontwikkeling in sector $\mathrm{s}$ in jaar $\mathrm{t}$;

$\mathrm{INV}_{\mathrm{st}} \quad=$ Reële investeringen in sector $\mathrm{s}$ in jaar $\mathrm{t}$;

$\mathrm{ARB}_{\mathrm{st}} \quad=$ Arbeidsvolume in sector $\mathrm{s}$ in jaar $\mathrm{t}$.

De conjuncturele situatie in een bedrijfstak kan worden gemeten door middel van de

7. Er zijn minimaal 2 EBB-waarnemingen (1990 en 1991) nodig om de AKT en de EBB voor opleidingen aan elkaar te kunnen relateren.

8. Voor een uitgebreider overzicht van de methodiek en de schattingsresultaten wordt verwezen naar Dekker, De Grip en Heijke (1992). 
bezettingsgraad. De feitelijke produktie in het desbetreffende jaar wordt dan gerelateerd aan de aanwezige produktiecapaciteit. Omdat er geen variabele beschikbaar is die de produktiecapaciteit weergeeft, wordt deze benaderd met het vijfjaarlijks voortschrijdend gemiddelde van de reële produktie in de desbetreffende sector.

$B E Z_{s t}=T W_{s t} /\left[1 / 5 \sum_{h=-2}^{2} T W_{s t+h}\right]$

$\mathrm{BEZ}_{\mathrm{st}}=$ Indicator conjuncturele situatie in sector $\mathrm{s}$ in jaar $\mathrm{t}$;

$\mathrm{TW}_{\mathrm{st}}=$ Reële toegevoegde waarde in sector $\mathrm{s}$ in jaar $\mathrm{t}$.

Om de beroepen- en opleidingenprognose consistent te houden met de uitkomsten van de bedrijfstakprognose van het CPB wordt gebruik gemaakt van verdeelmodellen. Dit betekent dat niet de ontwikkelingen van de absolute aantallen werkenden worden geanalyseerd, maar de relatieve ontwikkelingen in de werkgelegenheid, met andere woorden: de analyse vindt plaats op aandelen en niet op de absolute aantallen. Daarbij is gebruik gemaakt van een multinomiaal logit model (zie ook Parks, 1980, Van Opstal, 1988 en Peeters, 1990). Een logit model heeft het voordeel dat de geschatte aandelen (van de beroepssegmenten in een bedrijfssector) automatisch optellen tot 1 . Het modified multinomial logit (MML) model geeft bovendien de mogelijkheid tot het incorporeren van zowel specificatiefouten als steekproeffouten.

In eerste instantie is uitgegaan van dezelfde specificatie als in Peeters (1990):

$\ln \frac{f_{b s t}}{f_{\text {ref } s t}}=\alpha \cdot \ln \frac{f_{\text {bst }-1}}{f_{\text {ref st }-1}}+\beta_{1 b} \cdot I N V A R B_{s t}+\beta_{2 b} \cdot B E Z_{s t}$

$f_{\text {bst }} \quad=$ Aandeel werkenden in beroepssegment $b$, bedrijfssector $s$ in jaar $t$

ref $\quad=$ referentiecategorie

De idee bij het opnemen van een vertraagde endogene variabele in (4.3) sluit aan bij de partial adjustment modellen (zie bv. Wallis, 1979), waarbij de optimale of gewenste verandering niet direct, maar met enige vertraging wordt gerealiseerd. De waarde van de coëfficiënt ligt dan tussen 0 (geen aanpassing) en 1 (directe aanpassing). Bij het schatten van (4.3) blijkt deze specificatie echter inflexibel te zijn ten aanzien van sectorale verschillen in met name de kapitaalintensiteit, hetgeen leidt tot grote verschillen in de waarden van de geschatte coëfficiënten van de 'technologievariabele' INVARB. Deze coëfficiënten worden dermate groot dat bepaalde beroepssegmenten totaal worden weggedrukt in een sector, terwijl andere beroepssegmenten explosief toenemen. Daarom is een aantal alternatieven opgesteld:

a) een ondergrens (van 150) instellen ten aanzien van de vereiste celvulling;

b) de vertraagde endogene vervangen door dummy-variabelen;

c) de vertraagde endogene specificeren per beroepssegment;

d) andere keuze van het referentie-beroepssegment; 
e) de kapitaalintensiteitsvariabele INVARB normeren.

Als eerste oplossing is gekozen voor het opstellen van een ondergrens en het normeren van de INVARB-variabele (de waarden in het eerste waarnemingsjaar worden op 1 genormeerd). Dit levert weliswaar meer geloofwaardige coëfficiënten op, maar de doorrekening van het model geeft nog steeds explosies van verschillende beroepenaandelen te zien.

Vanwege de problemen bij het doorrekenen is een andere modelspecificatie gekozen, waarbij de coëfficiënt van de vertraagde endogene nu per beroepssegment mag variëren:

$\ln \frac{f_{b s t}}{f_{\text {ref st }}}=\alpha_{b} \cdot \ln \frac{f_{b s t-1}}{f_{\text {ref st }-1}}+\beta_{1 b} \cdot I N V A R B_{s t}+\beta_{2 b} \cdot B E Z_{s t}$

De schattingsresultaten geven over het algemeen redelijke uitkomsten voor de vertraagde endogene, maar een klein aantal beroepssegmenten heeft grote coëfficiënten die zelfs boven de 1 uitkomen. In een model waarin de groei van het ene aandeel ten koste gaat van een ander aandeel betekent dit dat het model niet bruikbaar is.

Op basis van deze bevinding is besloten om af te zien van een model met vertraagde endogene variabelen en is gekozen voor een specificatie met dummies $(\alpha)$ naar beroep en sector in combinatie met de reeds eerder onderscheiden verklarende variabelen:

$\ln \frac{f_{b s t}}{f_{\text {ref st }}}=\alpha_{b s}+\beta_{1 b} \cdot I N V A R B_{s t}+\beta_{2 b} \cdot B E Z_{s t}$

Het schatten van deze specificatie resulteert in lagere residuen. Hiervoor is echter een groot aantal parameters (de dummy's) nodig.

Middels een F-toets wordt de verklaringskracht van het model bepaald. Hierbij wordt de voor het aantal vrijheidsgraden gecorrigeerde som van de residuen voor de verschillende modelvarianten met elkaar vergeleken. Van de beide exogenen heeft alleen de INVARB-variabele een significant van nul afwijkende parameterwaarde. Dit resulteert in de volgende uiteindelijke specificatie ${ }^{9}$ :

$\ln \frac{f_{b s t}}{f_{\text {ref st }}}=\alpha_{b s}+\beta_{1 b} \cdot I N V A R B_{s t}$

9. Behalve toetsing van de parameterwaarden vond er ook een controle op de plausibiliteit van de geschatte werkgelegenheidsgroei plaats. De plausibiliteitsgrens is vastgesteld op een maximale afwijking van 15 procentpunten van de procentuele werkgelegenheidsontwikkeling in de analyseperiode. 
De diverse specificaties van het model zijn ook nog geschat met behulp van de Weighted Least Squares methode (WLS), waarbij de covariantiematrix die in de MML-methode een rol speelt wordt vervangen door een diagonaalmatrix. De verschillen tussen de geschatte coëfficiënten van het WLS en het MML model zijn evenwel zeer klein en zeker gezien de grootte van de standaardfouten is dit verschil eigenlijk te verwaarlozen ${ }^{10}$. Omdat de MML-methode bij modellen met een groot aantal keuzemogelijkheden rekentechnische problemen geeft en in het opleidingenmodel behalve een sector- en een beroependimensie ook een opleidingsvariabele wordt opgenomen, wordt voor het opleidingenverdeelmodel verder gebruik gemaakt van de WLS-methode.

Indien in de te schatten modellen de variabelen niet significant blijken te zijn, of resulteren in implausibele resultaten is er het alternatief om een trendvariabele op te nemen. Hoewel deze trend een weergave kan zijn van een aantal economische processen, typeren we dit model toch als het 'naïeve' model, omdat expliciete economische variabelen ontbreken.

Tenslotte wordt binnen het beroepenmodel een vertaalslag gemaakt van de prognoses per beroepssegment naar werkgelegenheidsprognoses per beroepsklasse, het aggregatieniveau waarop in I-See! de beroepenprognose wordt weergegeven. Voor de beroepssegmenten uit meerdere beroepsklassen bestaan is via een eenvoudig trendmodel geverifieerd of de verhoudingen tussen de beroepsklassen binnen het segment significant verschuiven in de tijd.

$\ln \frac{f_{k b t}}{f_{\text {ref } b t}}=\alpha_{k b}+\beta_{1 k b} \cdot T_{t}$

$\mathrm{f}_{\mathrm{kbt}}=$ Aandeel werkenden in beroepsklasse $\mathrm{k}$, beroepssegment $\mathrm{b}$ in jaar $\mathrm{t}$;

$\mathrm{T}_{\mathrm{t}} \quad=$ Trend.

Indien dit het geval is, wordt deze trend geëxtrapoleerd voor de prognoseperiode. In geval van implausibele uitkomsten is de extrapolatie echter afgekapt. In een enkel geval is zelfs helemaal afgezien van het extrapoleren van de trendmatige ontwikkeling. Deze ingrepen zijn toegepast vanwege het feit dat de analyseperiode slechts uit vier waarnemingen bestaat, waardoor een extrapolatie van de trend gemakkelijk kan 'exploderen'.

\section{Het opleidingenmodel}

In het opleidingenmodel worden twee stappen onderscheiden. Eerst worden de aandelen van de opleidingsrichtingen per bedrijfssector en beroepssegment gemodelleerd. Daarna wordt per richting een model geschat waarin de verdeling over de opleidingsniveaus wordt gespecificeerd.

10. Waarschijnlijk is de benadering van het logit model met WLS terug te voeren op de korte tijdreeks: 4 waarnemingen in de tijd (zie ook Allison, 1984). Daarom zal het meer rekenintensieve MML model pas weer worden toegepast als er meer waarnemingen in de tijd beschikbaar komen. 
Behalve de in het beroepenmodel gebruikte technologievariabele INVARB wordt nu evenals in Van Opstal (1989) ook een 'aanbod'variabele in het model opgenomen: de potentiële beroepsbevolking naar opleidingsrichting (en eventueel -niveau). Zeker bij de vraag naar opgeleiden kan er sprake zijn van aanbodeffecten. Zo kan er verdringing van lager opgeleiden uit hun beroepenveld optreden door het relatief grote aanbod van hoger opgeleiden, die aantrekkelijker kunnen zijn door hun hogere produktiviteit en -door het ruimere aanbod- gedaalde relatieve loonvoet. Hiermee vervalt de eerder gemaakte veronderstelling van een constante loonstructuur. De veronderstelling van een constante invloed van de loonstructuur op de werkgelegenheidsstructuur blijft echter wel gelden. Wegens het ontbreken van (gedesaggregeerde) loongegevens wordt verondersteld dat een groot aandeel van een bepaalde categorie opgeleiden in de potentiële beroepsbevolking overeenkomt met een ruim aanbod, met een overeenkomstige lage relatieve loonvoet, waardoor het aandeel in de werkgelegenheid toeneemt. men daarom het aandeel van een bepaalde opleidingscategorie in de potentiële beroepsbevolking als verklarende variabele op in het opleidingenmodel. Dit geeft voor de eerste stap in het opleidingenmodel, waarin de werkgelegenheidsontwikke-lingen per opleidingsrichting wordt geschat, de volgende vergelijking:

$\ln \frac{f_{\text {rbst }}}{f_{\text {ref bst }}}=\alpha_{b s}+\beta_{1 s} \cdot I N V A R B_{s t}+\beta_{2 s} \cdot P B E R_{r t}$

$f_{r b s t}=$ Aantal werkenden in opleidingsrichting $r$ in beroepssegment $b$, sector $s$ in jaar $t$;

$\mathrm{PBER}_{\mathrm{rt}}=$ Aantal personen in de potentiële beroepsbevolking met opleidingsrichting $\mathrm{r}$ in jaar $\mathrm{t}$.

Het opnemen van de PBER-variabele leidt echter tot implausibele uitkomsten, vermoedelijk als gevolg van multicollineariteit met de technologievariabele. Herschatting van het model zonder PBER-variabele resulteert echter nog steeds in ongeloofwaardige uitkomsten. De insignificantie van beide verklarende variabelen leidt tot de conclusie dat binnen de verschillende beroepssegmenten weinig substitutie tussen arbeidskrachten met een verschillende opleidingsrichting plaatsvindt. Als gevolg hiervan is voor een eenvoudig trendmodel gekozen:

$\ln \frac{f_{\text {rbst }}}{f_{\text {ref bst }}}=\alpha_{r b}+\alpha_{r s}+\beta_{1 r} \cdot T_{t}$

In de tweede stap, het niveaumodel, wordt gestart met dezelfde variabelen als in het richtingenmodel: INVARB en PBER. De parameters van de technologievariabele blijken echter niet significant van nul te verschillen. Voor een deel is dat terug te voeren op het feit dat de analyse plaatsvindt per bedrijfstak én beroepssegment, waardoor de celvulling in een aantal gevallen erg klein wordt. Vanwege de insignificantie van de sectorspecifieke variabele INVARB en de geringe celvulling is besloten om de gegevens te aggregeren over bedrijfstakken. Daardoor verdwijnt de sectordimensie uit het model, maar is wel een betere celvulling verkregen. Bovendien wordt de ondergrens met betrekking tot het opnemen van een cel verhoogd van 150 naar 500 . 
$\ln \frac{f_{n r b t}}{f_{\text {ref rbt }}}=\alpha_{n r b}+\beta_{1 n r} \cdot P B E R_{n r t}$

$\mathrm{f}_{\mathrm{nrbt}}=$ Aantal werkenden met opleidingsniveau $\mathrm{n}$ in opleidingsrichting $\mathrm{r}$, beroepssegment $\mathrm{b}$ in jaar $\mathrm{t}$.

De parameterschattingen voor de aanbodvariabele zijn in dit geval weliswaar significant, maar bereiken implausibele waarden. Daarop is besloten om over te gaan op een model waarin de dummyvariabelen worden vervangen door een vertraagde endogene variabele:

$\ln \frac{f_{n r b t}}{f_{\text {ref } r b t}}=\rho_{n r} \cdot \ln \frac{f_{n r b t-1}}{f_{\text {ref } r-1}}+\beta_{1 n r} \cdot P B E R_{r b t}$

Vanuit de combinaties opleidingsrichting en -niveau is waar nodig nog verbijzonderd naar afzonderlijke opleidingstypen. Evenals bij de beroepsklassen is op basis van een eenvoudig trendmodel nagegaan of de verhoudingen tussen het aantal werkenden van de verschillende opleidingstypen binnen een richting-niveau combinatie significant veranderen in de tijd. Net als in het beroepenmodel wordt er ingeval van 'exploderende' trends weer afgekapt, of wordt er alsnog afgezien van het extrapoleren van de trendmatige ontwikkeling. In beginsel is dus voor deze verdere verbijzondering naar opleidingstypen uitgegaan van de vergelijking:

$\ln \frac{f_{\text {onrt }}}{f_{\text {ref nrt }}}=\alpha_{\text {onr }}+\beta_{\text {ionr }} \cdot T_{t}$

$f_{\text {onrt }}=$ Aandeel werkenden in opleidingstype $o$ in niveau $n$, richting $r$ in jaar $t$.

\subsection{Methodiek vervangingsvraag}

De vervangingsvraag is een niet te onderschatten component van het totale aantal baanopeningen voor nieuwkomers op de arbeidsmarkt. Immers, als de werkgelegenheid van een beroep of opleiding slechts minimaal groeit, kan de vraag die ontstaat als gevolg van vervroegde uittreding, pensionering en tijdelijke uittreding (met name van gehuwde vrouwen), nog zeer aanzienlijk zijn.

Voor het bepalen van de vervangingsvraag zou in principe een uitgebreid verklarend model kunnen worden ontwikkeld. Het ontbreken van de benodigde stroomgegevens en het feit dat er voor de exogenen van het model een voorspelling voor de prognoseperiode beschikbaar zou moeten zijn, leiden er toe dat een dergelijke aanpak minder voor de hand ligt. In plaats daarvan is gekozen voor de in demografische analyses vaker gebruikte cohort-componenten methode op basis van de geslachts- en leeftijdsopbouw van de beroepsbeoefenaren (zie Willems en De Grip, 1990 en De Grip en Willems, 1992).

Met de vervangingsvraag per beroepsklasse wordt de vraag naar arbeidskrachten bedoeld die zou ontstaan als het verloop moet worden opgevuld door een beroepsbeoefenaar met hetzelfde 
beroep als de voorganger. Ingeval van een toename van de werkgelegenheid is de vervangingsvraag dan gelijk aan het aantal werkenden dat hun baan verlaat (in een bepaalde periode). Deze vacatures moeten immers eerst worden 'aangevuld' tot het oude werkgelegenheidsniveau voordat er sprake kan zijn van uitbreidingsvraag. Ingeval van een daling van de werkgelegenheid in een beroepsklasse worden niet alle vacatures opgevuld. Er dient dus rekening gehouden te worden met de krimp in de werkgelegenheid. Dit gebeurt door bij de bepaling van de vervangingsvraag in geval van daling van de werkgelegenheid in een beroepsklasse niet uit te gaan van het aantal vertrekkenden, maar van het aantal instromers in deze beroepsklasse.

Bij de bepaling van de vervangingsvraag per beroepsklasse wordt eerst voor de 'historische periode' 1981-1985 de in- en uitstroom per beroepsklasse bepaald. Vanwege het feit dat er geen geschikte data beschikbaar zijn om deze mobiliteitsstromen weer te geven, wordt daarbij gebruik gemaakt van standcijfers. Daartoe worden de zogenaamde 'cohort-change rates' bepaald. Deze ratio's geven de verhouding weer tussen het aantal werkenden in een beroepsklasse van een bepaald (geslachtsspecifiek) geboortecohort op twee tijdstippen. In symbolen kunnen de cohort-change rates worden weergegeven als ${ }^{11}$ :

${ }_{k} \dot{W}_{i, a}^{t, n}=\frac{{ }_{k} W_{i, a+n}^{t}}{{ }_{k} W_{i, a}^{t-n}}$

${ }_{k} \dot{W}_{i, a}^{t, n}=$ Cohort-change van de werkenden in beroepsklasse $\mathrm{i}$ met leeftijdsklasse a (met klassebreedte $k$ ) op tijdstip $t-n$ gedurende de periode $(t-n, t)$;

${ }_{k} W_{i, a}^{t}=$ Aantal werkenden in beroepsklasse i met leeftijdsklasse a (met klassebreedte $\mathrm{k}$ ) op tijdstip t.

Met behulp van de cohort-change rate wordt de netto uitstroom per beroepsklasse bepaald. De vervangingsvraag die wordt opgevuld door (her-)intredende personen van hetzelfde leeftijdscohort (en geslacht) is statistisch onbekend en wordt niet bij de bepaling van de vervangingsvraag meegenomen. Deze tekortkoming in de bepaling van de vervangingsvraag strookt echter met de opzet van het informatiesysteem onderwijs-arbeidsmarkt om vooral de werkgelegenheidsperspectieven voor nieuwkomers op de arbeidsmarkt in beeld te brengen (zie ook De Grip en Willems, 1992).

Om te komen tot de prognoses van de toekomstige vervangingsvraag vinden op de historische verloopquotes twee correcties plaats: een conjunctuurcorrectie en een correctie voor veranderingen van de participatiegraad. De conjunctuurcorrectie wordt bepaald als het verschil tussen de verandering in het totaal aantal werkenden en de verandering van de beroepsbevolking in het verleden. Op deze wijze worden de cohort-change rates 'conjunctuurneutraal' gemaakt. De correctie voor de participatiegraad bestaat uit het verschil

11. In de notatie is omwille van overzichtelijkheid de geslachtsindex weggelaten. 
tussen de groei van de beroepsbevolking in de historische en de prognoseperiode. Beide correctiefactoren zijn geslachts- en leeftijdsspecifiek, en voor alle beroepsklassen gelijk.

De geprognosticeerde netto in- of uitstroomperunages per leeftijdsklasse zijn dan als volgt:

$$
{ }_{k} \dot{W}_{i, a}^{t, m}={ }_{k} \dot{W}_{i, a}^{t, n}-{ }_{k} \dot{W} \dot{P}_{a}^{t, n}+{ }_{k} B \dot{B}_{a}^{t, m}
$$

${ }_{k} \dot{W}_{i, a}^{t, m}=\quad$ Verwachte gemiddelde jaarlijks netto in- of uitstroomperunage van werkenden in beroepsklasse $i$ en leeftijdsklasse a (met klassebreedte $k$ ) op tijdstip $t$ gedurende de voorspelperiode $(t, t+m)$;

${ }_{k} \dot{B}_{a}^{t, m}=\quad$ Verwacht gemiddeld jaarlijks groeiperunage van de totale beroepsbevolking in leeftijdsklasse a (met klassebreedte $k$ ) op tijdstip $t$ gedurende de prognoseperiode $(t, t+m)$;

${ }_{k} W P_{a}^{t, n}=\quad$ Gemiddeld jaarlijks groeiperunage van het totale aantal werkzame personen in leeftijdsklasse a (met klassebreedte $k$ ) op tijdstip $t-n$ gedurende de periode $(t-n, t)$.

Tenslotte worden de historische verlooppercentages per geslachts- en leeftijdsklasse voor een beroepskiasse geprojecteerd op de geslachts- en leeftijdsopbouw van de werkenden in de desbetreffende beroepsklasse aan het begin van de prognoseperiode. De toekomstige vervangingsvraag wordt analoog aan de bepaling van de vervangingsvraag in de historische periode bepaald. Dit betekent dat de toekomstige vervangingsvraag voor groeiberoepen gelijk is aan de verwachte netto uitstroom in de prognoseperiode, terwijl voor krimpberoepen de toekomstige vervangingsvraag wordt gedefinieerd als de verwachte netto instroom in deze periode.

De vervangingsvraag per opleidingstype wordt op analoge wijze bepaald, waarbij dus nu per opleidingstype leeftijdscohorten naar geslacht worden onderscheiden. Wel is de interpretatie van de uitkomsten afwijkend van de vervangingsvraag per beroepsklasse. De vervangingsvraag per opleidingstype wordt namelijk niet beïnvloed door de beroepsmobiliteit. Indien een arbeidskracht met een bepaalde opleidingsachtergrond van beroepsklasse verandert, komt er per saldo geen arbeidsplaats vrij voor een nieuwkomer met dezelfde opleidingsachtergrond.

\subsection{Methodiek arbeidsmarktinstroom van schoolverlaters}

Evenals de prognose van de uitbreidingsvraag is ook de raming van de toekomstige uitstroom uit het onderwijs naar de arbeidsmarkt gebaseerd op een verdeelmodel. Uitgaande van de SKILL-onderwijsprognoses van het Ministerie van Onderwijs en Wetenschappen (1990), wordt in een aantal stappen een prognose van de arbeidsmarktinstroom van schoolverlaters per ROA- 
opleidingstype geconstrueerd ${ }^{12}$.

Het rekenmodel wordt gekenmerkt door een stapsgewijze opbouw, die in figuur 2 schematisch is weergegeven. In de eerste stap wordt de uitstroom uit het regulier voltijdonderwijs per ROAopleidingstype berekend. Ongediplomeerde schoolverlaters worden daarbij toegerekend aan hun hoogst voltooide (voor)opleiding. Met de prognose van de uitstroom uit het regulier voltijdonderwijs ligt de totale toekomstige instroom van schoolverlaters op de arbeidsmarkt vast. Degenen die uitstromen uit het regulier voltijdonderwijs kunnen echter doorstromen naar een vorm van niet-regulier voltijdonderwijs of naar een deeltijdopleiding. Wanneer iemand een dergelijke opleiding met een diploma afsluit en de gevolgde opleiding ligt op een hoger niveau dan de genoten vooropleiding, dan vermindert de (potentiële) arbeidsmarktinstroom vanuit de opleidingscategorie waartoe de vooropleiding behoort, terwijl de arbeidsmarktinstroom in de categorie waartoe de deeltijd- of de niet-reguliere voltijdopleiding wordt gerekend toeneemt.

Deze herverdeling van regulier voltijd- naar niet-regulier voltijd- of deeltijdonderwijs vindt in de tweede stap van de raming plaats. Om de herverdeling te kunnen uitvoeren, is het noodzakelijk om niet alleen de 'vervolgopleiding' te registreren, maar ook de vooropleiding in het regulier voltijdonderwijs. Dit legt in de praktijk een grote claim op de kwaliteit van de data. Immers, er moet niet alleen een registratie van de aantallen gediplomeerden die uitstromen naar de arbeidsmarkt aanwezig zijn, maar ook de vooropleiding dient bekend te zijn. Dit laatste is nodig om de vereiste correctie op de uitstroom uit het regulier voltijdonderwijs te kunnen aanbrengen. $\mathrm{Na}$ de herverdeling van de uitstroom uit het regulier voltijdonderwijs resulteert de gewenste prognose van de toekomstige instroom van schoolverlaters op de arbeidsmarkt per ROAopleidingstype.

12. In 1991 zijn de SKILL-prognoses vervangen door de zogenaamde Referentieraming (Ministerie van Onderwijs en Wetenschappen, 1991). Daarvan kon echter voor deze studie nog geen gebruik worden gemaakt (zie verder Berendsen, Dekker, De Grip en Van de Loo, 1992). 
Figuur 2. Globaal schema van de raming van de toekomstige arbeidsmarktinstroom van schoolverlaters

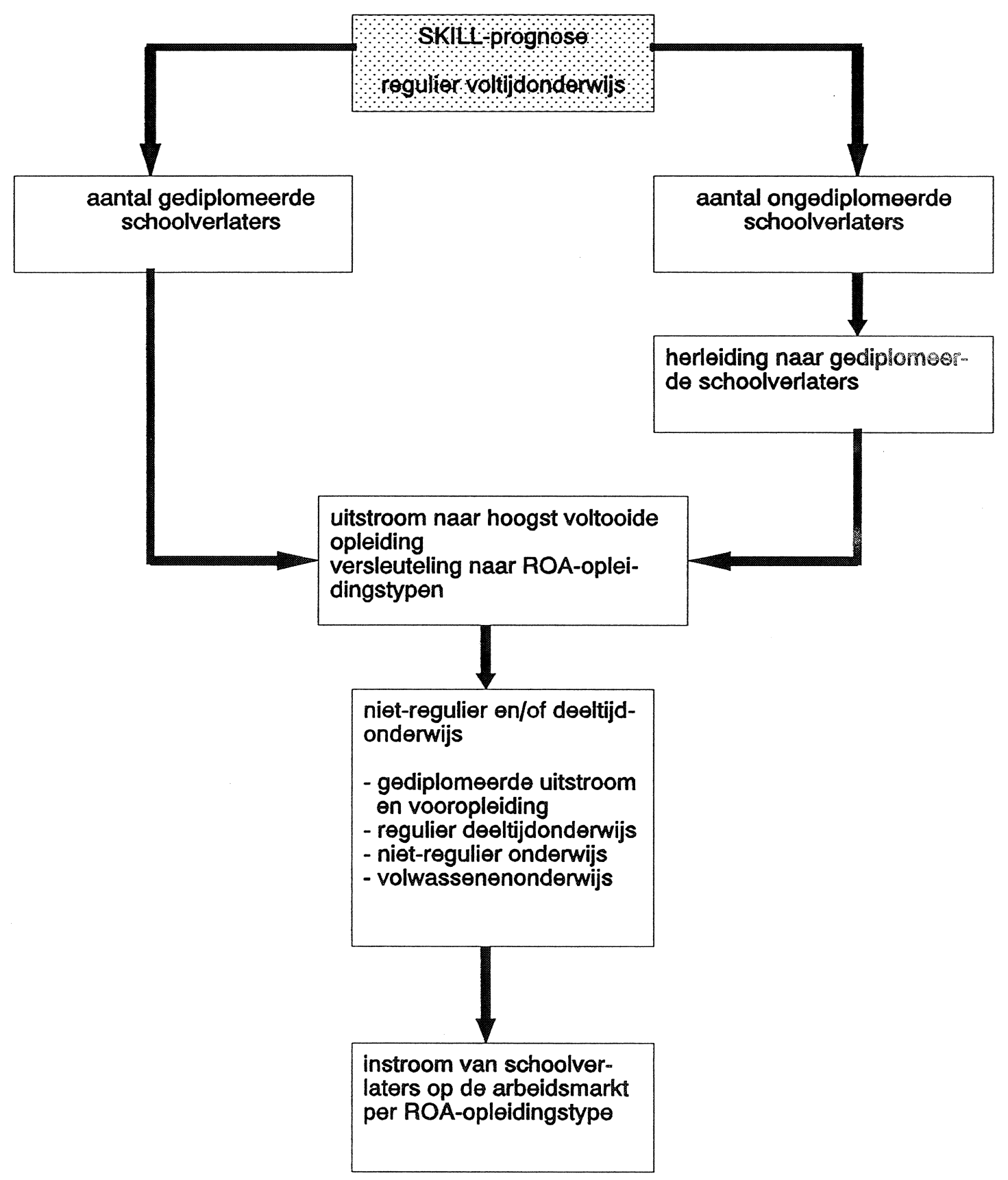


In tegenstelling tot de vraagmodellen ligt de nadruk bij de door het ROA uitgevoerde werkzaamheden niet op het analytische vlak (het schatten van parameters van verklarende variabelen), maar op het doorrekenen van doorstroom- (en herkomst-) coëfficiënten. De schatting van parameters vindt namelijk reeds in het SKILL-model plaats, waarvan de prognoses worden verbijzonderd naar de ROA-opleidingstypen. Deze aanpak komt overeen met de aanpak bij de vraagmodellen waar ook wordt gestart vanuit externe bedrijfstakprognoses, die via verdeelmodellen worden omgezet naar beroepsklasse- en opleidingstypeprognoses. Het externe model voor de instroomraming (SKILL) genereert een raming van het aantal schoolverlaters naar schoolsoort en diplomabezit. Het ROA transformeert deze gediplomeerde schoolverlaters, waarbij de ongediplomeerde schoolverlaters worden toegerekend aan de hoogst voltooide vooropleiding. Met name het verbijzonderen van de instroomgegevens is echter geen sinecure. $\mathrm{Er}$ is namelijk een uitgebreide set van aanvullende opleidingsgegevens nodig, die volgens zeer verschillende classificaties zijn ingedeeld.

\subsection{Typeringen van de prognoses}

Evenals bij de actuele arbeidsmarktdata en -indicatoren worden de kwantitatieve prognoseresultaten omgezet in een kwalitatieve typering van deze resulaten, omdat met name bij prognoses moet worden voorkomen dat de met onzekerheid omgeven uitkomsten worden geïnterpreteerd als absolute waarhden ('een groei van $5,1 \%$ is beter dan een groei van $4,7 \%$ ')

\section{Beroepsklasse}

De typering van de prognoses van de uitbreidings- en de vervangingsvraag per beroepsklasse zijn gebaseerd op de volgende indelingen ${ }^{13}$ :

Typering uitbreidingsvraag (UVB):

$\begin{aligned} & \text { UVB } \leq-18 \text { erg laag } \\ -18 & <\text { UVB } \leq 0 \text { laag } \\ 0 & <\text { UVB } \leq 13 \text { gemiddeld } \\ 13 & <\text { UVB } \leq 26 \text { hoog } \\ 26 & <\text { UVB }\end{aligned}$

Typering vervangingsvraag (VVB):

$\begin{aligned} & \text { VVB } \leq 5 \text { erg laag } \\ 5<\text { VVB } & \leq 9 \text { laag } \\ 9 & <\text { VVB } \leq 14 \text { gemiddeld } \\ 14 & <\text { VVB } \leq 18 \text { hoog } \\ 18 & <\text { VVB }\end{aligned}$

13. Voor nadere informatie omtrent de totstandkoming van de grenzenindeling wordt verwezen naar Wieling, De Grip en Willems (1990). 
De som van de positieve uitbreidingsvraag en de vervangingsvraag geeft de totale vraag naar nieuwkomers (de zogenaamde baanopeningen) voor de periode 1989-1994. Hierbij wordt opgemerkt dat de vervangingsvraag per definitie niet negatief kan zijn. Voor het bepalen van de baanopeningen wordt bovendien, mede in verband met de berekeningswijze van de vervangingsvraag, de uitbreidingsvraag, op nul gesteld als deze negatief is. Het aantal baanopeningen is in dat geval dus gelijk aan de vervangingsvraag. De typering van de totale vraag per beroepsklasse is als volgt:

Typering totale vraag (TVB):

$$
\begin{aligned}
& \text { TVB } \leq 3 \text { erg laag } \\
& 3<\text { TVB } \leq 13 \text { laag } \\
& 13<\text { TVB } \leq 27 \text { gemiddeld } \\
& 27<\text { TVB } \leq 37 \text { hoog } \\
& 37<\text { TVB }
\end{aligned}
$$

\section{Opleidingstype}

Behalve de uitbreidings-, de vervangingsvraag en de baanopeningen is, zoals gezegd, voor opleidingstypen ook een prognose van de instroom op de arbeidsmarkt in I-See! opgenomen. Voor de diverse prognoses naar opleidingstype zijn de typeringen als volgt:

Typering uitbreidingsvraag (UVO):

$$
\begin{aligned}
& \text { UVO } \leq-4 \text { erg laag } \\
-4 & <\text { UVO } \leq 5 \text { laag } \\
5 & <\text { UVO } \leq 17 \text { gemiddeld } \\
17 & <\text { UVO } \leq 26 \text { hoog } \\
26 & <\text { UVO } \quad \text { erg hoog }
\end{aligned}
$$

Typering vervangingsvraag (VVO):

$$
\begin{aligned}
& \text { VVO } \leq 4 \text { erg laag } \\
4 & <\text { VVO } \leq 7 \text { laag } \\
7 & <\text { VVO } \leq 12 \text { gemiddeld } \\
12 & <\text { VVO } \leq 15 \text { hoog } \\
15 & <\text { VVO }
\end{aligned}
$$

De som van de uitbreidings- en de vervangingsvraag geeft de baanopeningen per opleidingstype voor de periode 1989-1994. Net als bij de beroepsklassen wordt bij een negatieve uitbreidingsvraag het aantal baanopeningen gelijk gesteld aan de (niet-negatieve) vervangingsvraag. 
Typering totale vraag (TVO):

$$
\begin{aligned}
& \text { TVO } \leq 8 \text { erg laag } \\
8<\text { TVO } & \leq 16 \text { laag } \\
16<\text { TVO } \leq 27 \text { gemiddeld } & \leq 35 \text { hoog } \\
27<\text { TVO } \leq 3 \text { erg hoog } & \leq \text { TVO }
\end{aligned}
$$

Typering instroom (INS):

$$
\begin{aligned}
& \text { INS } \leq 8 \text { erg laag } \\
8 & <\text { INS } \leq 15 \text { laag } \\
15 & <\text { INS } \leq 26 \text { gemiddeld } \\
26 & <\text { INS } \leq 47 \text { hoog } \\
47 & <\text { INS }
\end{aligned}
$$

\subsection{Typering arbeidsmarktperspectieven}

Door een confrontatie te maken van de verwachte vraag met het verwachte aanbod van nieuwkomers, kan een indicatie worden verkregen van de toekomstige arbeidsmarktsituatie per opleidingstype. Dit gebeurt met behulp van de Indicator Toekomstige Arbeidsmarktsituatie (ITA). Deze wordt als volgt bepaald:

$I T A=\frac{\left(E_{89}+I N S+W K L H_{89}\right) / E_{89}}{\left(E_{89}+U V+V V\right) / E_{89}}$

$\mathrm{E}_{89} \quad=$ Werkgelegenheid in 1989

INS = Verwachte instroom van schoolverlaters 1989-1994

$\mathrm{WKLH}_{89}=$ Aantal kortdurig werklozen $1989^{14}$

UV $\quad=$ Verwachte uitbreidingsvraag 1989-1994

VV = Verwachte vervangingsvraag 1989-1994

Bij een indicatorwaarde gelijk aan 1 zijn de verwachte vraag en het verwachte aanbod in evenwicht ${ }^{15}$. Naarmate de waarde van de ITA hoger is, is er sprake van een slechter arbeidsmarktperspectief.

14. Het aantal kortdurig werklozen in 1989 is niet rechtstreeks beschikbaar. Het kan evenwel worden bepaald door het aantal ingeschrevenen in 1989 te vermenigvuldigen met het aandeel van de kortdurig werklozen in het totaal aantal ingeschrevenen in 1991.

15. Door het opnemen van de werkgelegenheid $\left(E_{89}\right)$ in de ITA wordt deze ongevoeliger voor kleine schommelingen in de prognoseresultaten. 
Typering indicator toekomstige arbeidsmarktsituatie opleidingstype (ITA):

$$
\begin{array}{r}
\text { ITA } \leq 1,00 \text { goed arbeidsmarktperspectief } \\
1,00<\text { ITA } \leq 1,05 \text { redelijk arbeidsmarktperspectief } \\
1,05<\text { ITA } \leq 1,10 \text { matig arbeidsmarktperspectief } \\
1,10<\text { ITA }
\end{array}
$$

Ten opzichte van de vorige versie zijn de grenzen van de ITA naar beneden bijgesteld. Dit is mede het gevolg van het feit dat de uitbreidingsvraag-, de vervangingsvraag- en het werkloosheidspercentage worden bepaald op basis van het aantal werkenden uit de $\mathrm{EBB}^{16}$, waarin een veel groter aantal werkenden wordt gemeten dan in de AKT. Het aanbod zoals dat uit de SKILL-prognoses volgt is echter onveranderd gebleven. Dit veroorzaakt een daling van de ITA over alle opleidingstypen. Het CBS gaat volgend jaar over op een nieuwe definitie van werkzame personen, waarbij werkenden minimaal 12 uur dienen te werken om mee te tellen in de definitie van werkzame personen. Dit zal de eenmalige daling van de ITA naar alle waarschijnlijkheid weer opheffen, omdat door deze nieuwe ondergrens het gemeten aantal werkenden kleiner zal zijn.

\section{Arbeidsmarktperspectief}

Voor elk van de besproken arbeidsmarktbegrippen is een kwalitatieve typering gegeven. Wat echter nog ontbreekt is een samenvatting van de arbeidsmarktsituatie van de opleiding of het beroep, op basis van een combinatie van de genoemde arbeidsmarktindicatoren en -prognoses.

In I-See! is getracht een samenvattende beschrijving van de arbeidsmarktsituatie van een opleiding te construeren op basis van de werkloosheidsclassificatie, de indicator toekomstige arbeidsmarktsituatie en de spreidingsindicatoren naar branche- en beroepsklasse. Voor de samenvattende beschrijving van de arbeidsmarktsituatie per beroepsklasse wordt gebruik gemaakt van de typering van de totale vraag, de conjunctuurindicator en de branchespreiding. Eventueel wordt deze beschrijving nog aangevuld met prognoses voor kleine specifieke deelmarkten. Deze zijn echter tot nu toe alleen beschikbaar voor de leraren (opleidingstype én beroepsklasse).

De teksten in I-See! met het samenvattende arbeidsmarktperspectief zijn per beroepsklasse respectievelijk opleidingstype geschreven op basis van de bovengenoemde factoren afzonderlijk en dus niet tot stand gekomen via een typering van een nieuwe samenvattende kwantitatieve variabele. Derhalve volstaan we hier met een voorbeeld van het samenvattende arbeidsmarktperspectief voor een beroepsklasse en een opleidingstype.

Beroepsklasse: Docenten hoger en voortgezet onderwijs

'Voor de nabije toekomst is de vraag naar nieuwkomers in deze beroepsklasse verhoudingsgewijs laag. De conjunctuurgevoeligheid van de werkgelegenheid is klein, maar de

16. Het CPB heeft haar werkgelegenheidsprognoses afgestemd op de EBB-gegevens. 
uitwijkmogelijkheden naar andere bedrijfssectoren zijn ook erg klein. De arbeidsmarktperspectieven van de verschillende categorieën leerkrachten lopen echter sterk uiteen. Voor docenten economie-administratie, techniek, agrarische vakken, nautische vakken, exacte vakken en klassieke talen zijn de vooruitzichten goed. Voor docenten frans/engels/duits gelden matige vooruitzichten en voor docenten overige talen, sociaal-culturele vakken, expressievakken en huishoudelijke en sociaal-pedagogische vakken gelden daarentegen slechte arbeidsmarktvooruitzichten. Bron: KASKI/NEI/ROA.'

Opleidingstype: Lager transport-, communicatie- en verkeersonderwijs 'Momenteel is de werkloosheid voor dit opleidingstype laag. Voor de nabije toekomst zijn de arbeidsmarktperspectieven bovendien goed. De uitwijkmogelijkheden naar andere beroepen zijn echter erg klein; de uitwijkmogelijkheden naar andere bedrijfssectoren zijn eveneens klein. Voor de verschillende regio's in ons land is de werkloosheid voor dit opleidingstype als volgt te typeren: In vergelijking met de landelijk gemiddelde werkloosheid voor dit opleidingstype is de werkloosheid relatief laag in de regio's Friesland, Flevoland, Amsterdam/Zaanstreek/Waterland, Rijnstreek, Rijnmond. Daarentegen is de werkloosheid relatief hoog in de regio's Kennemer/Amstel- en Meerlanden, Groningen, Zeeland. In de regio Noord-Holland Noord, ligt de werkloosheid rond het landelijk gemiddelde van dit opleidingstype. Bron: ROA.' 


\section{SCHEMATISCH OVERZICHT VAN DE ARBEIDSMARKTMODULE}

\subsection{Schermopbouw}

In de voorgaande hoofdstukken is aandacht besteed aan de inhoudelijke kant van de informatie en de totstandkoming ervan. In dit hoofdstuk wordt een overzicht gegeven van de wijze van presentatie van de I-See!-informatie op het beeldscherm, de zgn. user-interface. Technische details worden hier niet besproken, daarvoor wordt verwezen naar het datamodel van I-See!. Wel wordt in bijlage 1 een voorbeeld gegeven van de transformatie van ruwe arbeidsmarktinformatie tot de I-See! schermtekst.

In figuur 3 wordt een schematisch overzicht gegeven van een I-See! scherm. Het scherm bestaat uit vier onderdelen: een A-deel waarin de namen van de richting, opleiding, instelling, beroep e.d. worden weergegeven, een B-deel waarin de keuzemogelijkheden met betrekking tot de eindinformatie staan weergegeven, een C-deel waarin de opties uit het B-deel worden toegelicht en een D-deel waarin de feitelijke informatie wordt gepresenteerd.

Figuur 3. Indeling I-See! beeldscherm

\begin{tabular}{||l||l||}
\hline A-deel & $\begin{array}{l}\text { B- } \\
\text { deel }\end{array}$ \\
\hline \hline C-deel & \\
\hline D-deel & \\
\hline
\end{tabular}

Deze vierdeling is voor alle modulen binnen I-See! dezelfde. Middels functietoetsen kan men voor- en achteruit door het gemaakte keuzetraject bladeren, twee beroepen of opleidingen met elkaar vergelijken en een woordenlijst oproepen, waarin specifieke termen worden toegelicht.

\subsection{Schermstructuur arbeidsmarktmodule}

Kenmerkend voor de arbeidsmarktmodule is dat zowel beroeps(klasse)- als opleidings(type) informatie wordt gepresenteerd. Toch is getracht zoveel mogelijk symmetrie in de informatie aan te brengen, door voor zowel beroepsklassen als opleidingstypen dezelfde soort informatie te geven (aantal werkenden, risico-indicatoren, prognoses).

De arbeidsmarktmodule kan rechtstreeks worden benaderd of indirect via de beroepen-, of opleidingenmodule. Indien men direct kiest voor de arbeidsmarktmodule dient eerst te worden aangegeven of men informatie wil over beroepen of opleidingen. In beide gevallen hoeft niet 
meteen een keuze uit de 93 beroepsklassen of 49 opleidingstypen te worden gemaakt, maar kan via een tussenstap van respectievelijk sector en richting een preselectie worden gemaakt. Indien men via de beroepen- of opleidingenmodule in de arbeidsmarktmodule terecht komt hoeft er geen keuze te worden gemaakt, er is immers reeds een beroep c.q. opleiding in een van de voorgaande modules gekozen.

Bij de doorsteek van een andere module naar de arbeidsmarktinformatie wordt men overigens wel geconfronteerd met een verschil in aggregatieniveau. In de beroepenmodule worden bijvoorbeeld vijftienhonderd beroepen onderscheiden, terwijl de arbeidsmarktinformatie wordt gepresenteerd op beroepsgroep- (320) en beroepsklasse- (93) niveau. Ook voor opleidingen geldt dat de arbeidsmarktinformatie op een geaggregeerd niveau wordt gepresenteerd. De meer dan tienduizend opleidingen zijn hierbij geclusterd tot de genoemde 49 opleidingstypen.

Figuur 4. Schermopbouw arbeidsmarktmodule
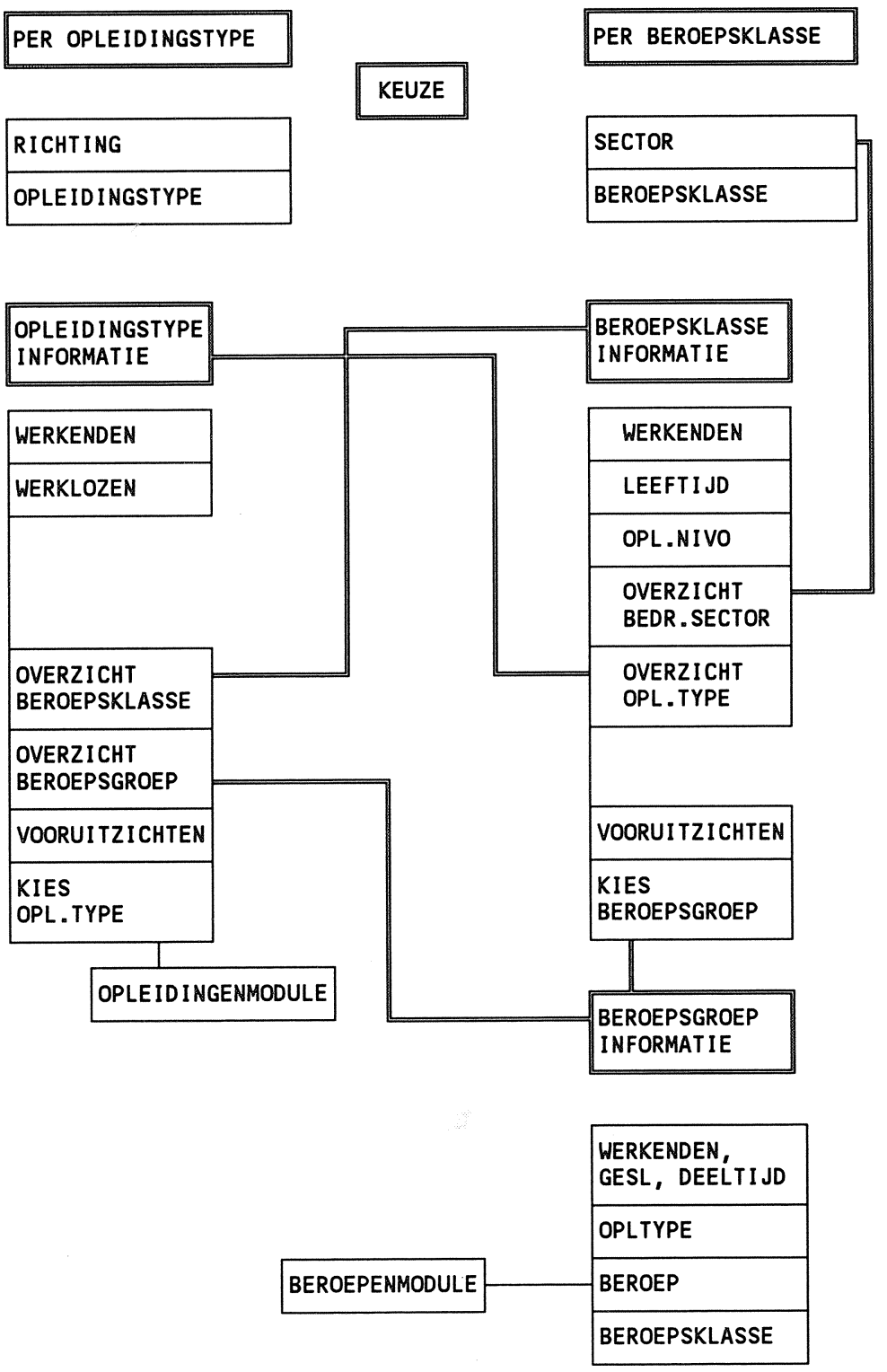
Ook binnen de arbeidsmarktmodule kan men, zoals uit het schematisch overzicht van de schermopbouw van de arbeidsmarktmodule in figuur 4 blijkt, switchen tussen arbeidsmarktinformatie over beroepsklassen en opleidingstypen. Middels deze 'hangmatten' (aan een beroepsklasse hangen verschillende opleidingstypen en vice versa) wordt ook duidelijk gemaakt dat de relatie tussen beroep en opleiding op de arbeidsmarkt niet eenduidig is.

De omkaderde blokken 'werkenden', 'werklozen', 'opleidingsniveau' e.d. kunnen in I-See! in het B-schermdeel (zie vorige paragraaf) worden gekozen. De actuele arbeidsmarktgegevens, indicatoren en prognoses, die in figuur 4 worden weergegeven, zijn in de voorgaande paragrafen reeds aan de orde geweest en deze zullen dan ook niet verder worden besproken.

Uit de in figuur 4 weergegeven schermopbouw van de arbeidsmarktmodule blijkt enerzijds de vlakke structuur van deze module (na de keuze van een beroepsklasse wordt er reeds eindinformatie over de arbeidsmarkt gepresenteerd), maar anderzijds legt deze structuur ook beperkingen op. De te presenteren informatie (b.v. 'werklozen') dient volgens de opzet van de arbeidsmarktmodule namelijk voor alle opleidingstypen of beroepsklassen volledig aanwezig te zijn, hetgeen niet altijd informatief is. Zo wordt bij de 'werkenden' het percentage zelfstandigen gepresenteerd, dat voor de beroepsklasse 'zelfstandige winkeliers' uiteraard $100 \%$ is en voor vele industrieberoepen (loondienst) $0 \%$ is. Anderzijds moet door de gehanteerde opzet ook informatie achterwege blijven, omdat bijvoorbeeld nog niet voor alle beroepsklassen of opleidingstypen op basis van de beschikbare statistische gegevens uit gehouden enquêtes onder afgestudeerden kan worden aangegeven hoe goed of slecht de aansluiting opleiding-beroep momenteel is. 


\section{BESLUIT}

In dit werkdocument is een overzicht gegeven van de arbeidsmarktinformatie zoals deze voor de derde versie van I-See! door het ROA is aangeleverd aan de opdrachtgever, het LDC.

Behalve een toelichting op de totstandkoming van de arbeidsmarktinformatie, opgesplitst in actuele data en indicatoren enerzijds en prognoses anderzijds, is ook een beeld geschetst van de schermopbouw van de arbeidsmarktmodule. Ten opzichte van de pilot fase van I-See! (De Grip, Heijke en Vos, 1987) heeft een aantal verbeteringen plaats gevonden. De modellen voor de prognoses zijn verbeterd en met name voor de prognose van de vervangingsvraag konden kwalitatief betere data worden gebruikt. Voor de actuele data en de arbeidsmarktindicatoren kon in deze derde release voor het eerst gebruik worden gemaakt van EBB-cijfers (periode 1988-1990) in plaats van de sterk verouderde AKT-data (tot 1985). Ook is voor beroepsklassen overgestapt op een verbeterde classificatie waarin de relatie opleiding-beroep beter tot zijn recht komt. Dit resulteert ook in een betere koppeling tussen de verschillende modules in I-See!. Tenslotte is er een begin gemaakt met het presenteren van regionale (werkloosheids)informatie per opleidingstype naar RBA-gebied. Een verdere detaillering van de prognoses naar opleiding en beroep heeft echter nog niet plaats kunnen vinden, mede vanwege het feit dat externe publikaties met middellange-termijn prognoses op gedesaggregeerd niveau amper beschikbaar zijn.

Ondanks bovenstaande verbeteringen is het raadzaam om te blijven streven naar verdere vervolmakingen, van zowel de achterliggende methoden en technieken, de basisgegevens, als de wijze van presenteren. Ook kan verdere invulling worden gegeven aan de regionalisering van de arbeidsmarktinformatie, zoals die in deze aanlevering al heeft plaatsgevonden voor de wekloosheidsgegevens. Voor volgend jaar staan met name verdere verbeteringen van de basisgegevens op het programma. Het CBS introduceert namelijk een (nieuwe) ondergrens van 12 uur werken in de definitie van werkzame personen. Dit impliceert dat de vanaf 1988 opgebouwde datareeks uit de EBB moet worden aangepast. Een verdere data-activiteit betreft het koppelen van de AKT-tijdreeks (1979-1985) aan de inmiddels ook al vier jaar lopende EBBdataset (1988-1991). Het beschikbaar komen van een langere tijdreeks is erg belangrijk voor het opstellen van prognoses van de toekomstige vraag naar opleiding en beroep. Voor de bepaling van de instroom van schoolverlaters zal worden overgestapt van de SKILL-data die oorspronkelijk van het CPB afkomstig zijn en later door het Ministerie van Onderwijs en Wetenschappen zijn overgenomen naar de Referentieraming van het Ministerie van Onderwijs en Wetenschappen. Binnen de prognosemethodieken zal de meeste aandacht uitgaan naar verdere verbetering van de modellen van de uitbreidingsvraag. 


\section{LITERATUUR}

Allisson, P.D. (1984), Event History Analysis Regression for Longitudinal Event Data, Sage University Paper series on Quantitative Applications in the Social Sciences, 07-046, Beverly Hills and London.

Beekman, Th.B.J., R.J.P. Dekker, A. de Grip, J.A.M. Heijke (1989), Een verklaring van de opleidingenstructuur van beroepen, ROA-W-1989/3, Maastricht.

Berendsen, H., R.J.P. Dekker, A. de Grip, P.J.E. van de Loo (1992), Prognose arbeidsmarktinstroom van schoolverlaters per opleidingstype, ROA-W-1992/2.

Bierings, H.B.A., C.A. van Bochove, J.C.M. Imbens (1990), De definitie van de beroepsbevolking, Supplement bij de sociaal-economische maandstatistiek, $\mathrm{nr}$. 2, CBS, Voorburg/Heerlen.

Dam, J.W. van, A. de Grip, J.A.M. Heijke (1988), Op zoek naar informatiebronnen over de arbeidsmarktpositie van academici, ROA-W-1988/3, Maastricht.

Dekker, R.J.P., A. de Grip, Th.B.J. Beekman, P.J.E. van de Loo, M.H. Wieling, E.J.T.A. Willems (1990), Rapportage I-See! 1990, ROA-R-1990/6, Maastricht.

Dekker, R.J.P., A. de Grip, J.A.M. Heijke (1988), Een verklaring van de beroepenstructuur van bedrijfstakken, ROA-W-1988/2, Maastricht.

Dekker, R.J.P., A. de Grip, J.A.M. Heijke (1992), The ROA Information System for Education and the Labour Market: Models and Methods, ROA, Maastricht.

Dekker, R.J.P., A. de Grip, P.J.E. van de Loo (1990), ROA-Beroepenclassificatie 1990, ROA-W1990/9, Maastricht.

Eijgenraam, C.J.J., E.M. Verkade (1988), BETA, een bedrijfstakkenmodel van de Nederlandse economie, CPB, Occasional Paper, no. 44, Den Haag.

Grip, A. de, J.A.M. Heijke (1988), Arbeidsmarktindicatoren: een inventarisatie, ROA-W-1988/1, Maastricht.

Grip, A. de, J.A.M. Heijke, J.W. van Dam, R.J.P. Dekker, M.H. Wieling (1988), Aanvulling arbeidsmarktmodule I-SEE project (wetenschappelijk onderwijs), ROA-R-1988/2, Maastricht.

Grip, A. de, J.A.M. Heijke, R.J.P. Dekker, Th.B.J. Beekman, H.M.M. Peeters (1989), De arbeidsmarktperspectieven van beroepsklassen en opleidingstypen in 1992: rapportage 1SEE!, ROA-R-1989/7, Maastricht. 
Grip, A. de, J.A.M. Heijke, R.J.P. Dekker, L.F.M. Groot, L.A. Vos (1987), De arbeidsmarkt perspectieven van studierichtingen in het wetenschappelijk onderwijs 1992: Arbeidsmarktmodule I-SEE project, ROA-R-1987/3, Maastricht.

Grip, A. de, J.A.M. Heijke, L.A. Vos (1987), Inventariserend onderzoek arbeidsmarktmodule ISEE project, ROA-R-1987/1, Maastricht.

Grip, A. de, R.K.W. van der Velden, M.H. Wieling (1991), Indicatoren aans/uiting onderwijs- en arbeidsmarkt MDGO; Enkele arbeidsmarktindicatoren op basis van de RUBSdata, ROA-R1991/2, Maastricht.

Grip, A. de, E.J.T.A. Willems (1992), De vervangingsvraag naar beroepsklasse tot 2000, OSAwerkdocument W96, Den Haag.

Koning, J. de (1987), Omvang en oorzaken van labour hoarding, Nederlands Economisch Instituut, Rotterdam.

Ministerie van Onderwijs en Wetenschappen (1990) SKILL 1990-II, Interne notitie, Zoetermeer.

Ministerie van Onderwijs en Wetenschappen (1991), Referentieraming 1991, 's-Gravenhage.

Opstal, R. van (1988), Estimation of manpower coefficients with a modified multinomial logit method, CPB, Research Memorandum, no. 41, 's-Gravenhage.

Opstal, R. van (1989) Arbeidsaanbod en werkgelegenheid naar 11 opleidingscategoriën 19852000; een actualisering van werkdocument 17, Interne notitie CPB II/1989/25, 'sGravenhage.

Parks, R.W. (1980), On the Estimation of Multinomial Logit Models from Relative Frequency Data, Journal of Economics, vol 13, pp 293-303.

Peeters, H.M.M. (1990), An Explanation of the Occupational and Educational Structure of Employment by means of Multinomial Logit, ROA-W-1990/4E, Maastricht.

Pere, H.M. (1986) Arbeidsmarktvoorlichting; Een voorstel voor interdisciplinaire opbouw, Centrum voor Beleidsanalyse en Advies, Nijmegen.

Researchcentrum voor Onderwijs en Arbeidsmarkt (1992), De arbeidsmarkt naar opleiding en beroep tot 1994, ROA-R-1992/1, Maastricht.

Researchcentrum voor Onderwijs en Arbeidsmarkt (1992), De arbeidsmarkt naar opleiding en beroep tot 1994. Statistische bijlage, ROA-R-1992/1B, Maastricht. 
Sheldon, G. (1985), Die berufliche und geografische Flexibilität, Institut für Arbeidsmarkt und Berufsforschung der Bundesanstalt für Arbeit, Beitrage AB 92, Nürnberg.

Wallis, K.F. (1979), Topics in applied econometrics, second edition, Basil Blackwell, Oxford.

Warnken, J. (1986), Zur Entwichlung der "internen" Anpassungsfälsigkeit der Bente bis zum Jahre 2000. Projektionen unter den Annahmen der Wachstumszenarien der Prognos-Studie, in: Mitteilungen aus der Arbeidsmarkt- und Berufsforschung.

Wieling, M.H., A. de Grip, E.J.T.A. Willems (1990), Een systematische kwalitatieve typering van arbeidsmarktinformatie, ROA-W-1990/8, Maastricht.

Wieling, M.H., R.J.P. Dekker, A. de Grip (1991), Landelijke en regionale werkloosheidsindicatoren 1991, ROA-R-1991/8, Maastricht.

Willems, E.J.T.A., A. de Grip (1990), Vervangingsvraagprognoses naar beroep en opleiding, ROA-W-1990/7, Maastricht. 
$-38-$

\section{BIJLAGE 1. TRANSFORMATIE VAN ARBEIDSMARKTINFORMATIE NAAR BEELDSCHERMTEKST}

Het zou te ver voeren om in dit werkdocument een compleet overzicht te geven van het datamodel en de user-interface. Wel wordt middels een voorbeeld aangegeven hoe de constructie van de schermteksten heeft plaatsgevonden.

Een schermtekst binnen de arbeidsmarktmodule is opgebouwd uit vaste tekst, waarin de variabelen met arbeidsmarktinformatie worden opgenomen. Voor de schermtekst van het aantal werkenden per opleidingstype is de tekst als volgt opgebouwd:

In de periode -VAR1 - waren gemiddeld -VAR2- personen werkzaam

die binnen het opleidingstype -VAR3-

een opleiding gevolgd hebben.

Verhoudingsgewijs is dit een -VAR4-.

Het aandeel van deze groep in de totale werkgelegenheid

is daarbij in deze periode -VAR5-.

Bron: -VAR6- Brondatum: -VAR7-

De variabele tekst wordt ingevuld vanuit de ROA-aanlevering, waarbij er eventueel een transformatie van de tekst van de variabelen wordt toegepast om de zinnen beter te laten lopen. De variabelen in de bovenstaande tekst zijn:

VAR1: histper-opltyp

VAR2: aantwerk-opltyp

VAR3: oplnaam

VAR4: kwalwerk-opltyp

er vindt een transformatie plaats:

erg groot wordt omgezet in: erg grote groep

groot

gemiddeld

klein

grote groep

groep van gemiddelde omvang

erg klein

kleine groep

erg kleine groep

VAR5: trdaand-opltyp

er vindt een transformatie plaats:

sterk stijgend wordt omgezet in:

stijgend

sterk toegenomen

constant

toegenomen

ongeveer hetzelfde gebleven

dalend

afgenomen

sterk dalend

sterk afgenomen

VAR6: bronhist-opltyp

VAR7: brndhist-opltyp 
Voor een bepaald opleidingstype ontstaat dan de volgende schermtekst:

In de periode 1990 waren gemiddeld 241000 personen werkzaam die binnen het opleidingstype middelbaar beroepsonderwijs persoonlijke verzorging een opleiding gevolgd hebben.

Verhoudingsgewijs is dit een erg grote groep.

Het aandeel van deze groep in de totale werkgelegenheid is daarbij in deze periode toegenomen.

Bron: CBS/ROA

Brondatum: 01-07-91 